\title{
Early Bursts of Disparity and the Reorganization of Character Integration
}

\author{
Peter J. Wagner \\ Dept. of Earth \& Atmospheric Sciences, and School of Biological Sciences \\ University of Nebraska \\ Lincoln, NE 20560 \\ pjwagner3@gmail.com
}

\begin{abstract}
Evolutionary biologists commonly explain "early bursts" of morphological disparity (i.e., diversity of anatomical types) in terms of subsequent integration among characters reducing probabilities of characters change. However, modules of linked characters themselves evolve, changing which characters are linked to one another and potentially allowing for rapid increases in disparity. Early bursts fit the expectations of integration/modularity reorganization in two ways: early disparity exceeds the expectations of simple independent change models, and early bursts correlate with stratigraphic incompatibility suggesting that multicharacter changes are followed by independent changes. This suggests that integrated changes sustained by the beneficial effects of some characters lead to selection for reduced integration among those characters, allowing both for reversals to primitive states for some characters and still different novel states for others. Subsequent reorganization of integration and modularity later constrains disparity. Thus, although modularity and integration might limit disparity most of the time, they periodically elevate disparity greatly.
\end{abstract}




\section{Introduction}

A common pattern in the fossil record is for the range of distinct anatomical forms (i.e., morphological disparity) to be high early in clade histories (Erwin 2007, Hughes et al. 2013). Explanations for such "early bursts" of disparity invoke theory from both ecology and evolutionary-developmental biology (Foote 1994, Wagner 1995b, Foote 1996a, Ciampaglio 2002, Gerber 2013): the former posits reduced opportunities for novel anatomies to succeed and the latter posits reduced opportunities for novel anatomies to arise. The predictions stemming from those models typically are framed in the context of systematic theory. This views characters (i.e., specific anatomical structures) as homologies and the units of morphological evolution (Patterson 1982). Combining these theories provides two explanations for early bursts of disparity. The first is that ecology and development limit plausible novel states, resulting in clades that rapidly exhaust the possible states to add little disparity even if rates of character change remain constant (Foote 1994, Wagner 2000b). The second is that frequencies of character change decrease, resulting in fewer opportunities for novel states to arise and/or flourish (Foote 1996a) and thus reduced increase of disparity.

Evolutionary-developmental theory also offers a model of homology and units of morphologic evolution that differs from that of systematic theory, and that provides an explanation for why evolvability should sometimes increase then decrease and thus create bursts of disparity (Wagner and Altenberg 1996). This theory treats character complexes (modules) as the unit of change, with distinct character states often appearing through interactions with other characters in the same complex rather than through independent processes (Wagner 1989). Although tighter integration among characters within a module should limit evolvability and disparity (Goswami and Polly 2010), modules themselves evolve by breaking up and reforming anew (Wagner 1996), resulting in different integration patterns among characters (Eble 2004, Goswami 2006). Intervals of integration/modularity reorganization among characters should elevate both rates of character change and thus encourage the evolution of novelties that greatly increases disparity (Davidson and Erwin 2006, Wagner 2007). If integration/modularity reorganization commonly delimits what paleontologists recognize as higher taxa, then this provides a third explanation for early bursts of disparity.

The three models for generating early bursts of disparity (exhaustion, elevated early rates of change and integration/modularity reorganization) all make unique predictions about the relationship between early disparity and both character compatibility and stratigraphic compatibility (Table 1). Character compatibility (Le 
Quesne 1969) measures whether pairs of characters necessarily require parallelisms or reversals. As frequencies of change among character states increase, reversals and parallelisms also increase and levels of compatibility decrease (O'Keefe and Wagner 2001). Simple inverse modeling can determine a (uniform) rate of independent character changes that maximizes the probability of observed compatibility within clade (Wagner and Estabrook 2015). If early disparity exceeds the expected disparity given this best uniform rate model, then we can reject exhaustion as the primary culprit of an early burst. The same approach applied only to the earliest taxa can establish the 2-rate (early vs. late) models of independent change maximizing the probability of compatibility among those early taxa (see Materials and Methods). If early disparity exceeds that expected from the 2-rate model of independent change, then we can reject elevated early rates of independent change as the sole cause of an early burst.

In addition to predicting that early disparity will exceed expectations given any independent change model (Table 1), the integration/modularity reorganization model predicts that stratigraphic compatibility also should be low. This premise is supported both by simulations and by unusually high stratigraphic compatibility in Cambrian trilobites (Wagner and Estabrook 2015), which show low phylogenetic conservation of integration patterns relative to later trilobites (Webster 2007, Webster and Zelditch 2011). Thus, integration/modularity reorganization predicts that early disparity exceeding the expectations of 2-rate models of independent change will correspond to overly low stratigraphic incompatibility given the same 2-rates models.

Table 1.

Alternative models for early bursts of disparity $(D)$, expected early disparity (E[early $D]$ and their expected associations. "Model" refers to the pattern underlying an early burst of disparity.

"Expectations" reflect both first principles and also outcomes of Monte Carlo analyses (see Methods).

Model

Exhaustion/Saturation

Elevated Early Rates of Change

Integration/Modularity Reorganization
Expectations

Early $D \leq \mathrm{E}[$ early $D$ ] given uniform rate of independent character change maximizing the probability of character compatibility among all taxa (=1-rate model).

Early $D>$ E[early $D$ ] given best 1-rate model of independent change;

Early $D \leq \mathrm{E}[$ early $D$ ] given independent change maximizing the probability of compatibility among the early and late taxa separately (= 2-rate model).

Early $D>$ E[early $D$ ] given best 1-rate model;

Early $D>$ E[early $D$ ] given best 2-rate model;

(Early $D-$ E[early $D$ ]) correlates with stratigraphic incompatibility. 


\section{Materials and Methods \\ Data assembly}

The analyses cover 257 published character matrices of 13+ ingroup taxa that were originally assembled for phylogenetic analyses (Appendix S1;

http://datadryad.org/resource/doi:10.5061/dryad.h5971). Only data sets with 13+ ingroup taxa were used in order to have a sample of at least 4 species when looking at disparity and rates in the earliest third of clade evolution. Because the tested hypotheses concern shifts at low taxonomic levels, only analyses of species or genera are used. This also avoids the heterogeneity in phylogenetic branch durations expected when analyzed taxa of variable ranks and taxonomic richness are analyzed. The one exception made for this rule is studies focusing on early members of clades that included token representation of later members. If the representatives were the oldest members of the derived taxon, then that stemmember was included. Otherwise, the taxon was excluded and only the older taxa were examined. Extant taxa are included only if they have fossil representatives. I exclude any characters not coded for extinct taxa these probably are nonfossilizable. I also exclude characters that are invariant within the ingroup. Polymorphic characters (i.e., those in which $2+$ conditions are observed in the same taxon) are set to states that maximized their stratigraphic compatibility. First and last appearance data come from several sources, with the original publications and the Paleobiology Database (http://www.paleobiodb.org/) being the two primary sources. Stratigraphic ranges for extant taxa reflect the first and last fossil occurrences of those taxa.

\section{Disparity calculations}

Disparity is measured here as the average pairwise dissimilarity among characters (Foote 1992, 1994, 1996b). Multistate characters are unordered, which means that any taxa are considered either different or the same for any character. This makes disparity:

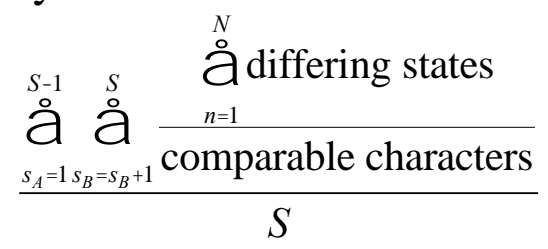

where $S$ is the number of taxa, $N$ is the number of characters, and "comparable characters" are all characters for which two contrasted taxa have an observed state rather than an unknown condition. The biggest factor increasing average pairwise dissimilarity is the addition of novel character states: with complete exhaustion of available character states, we expect disparity to peak at $v /(v+1)$, where $v$ is the 

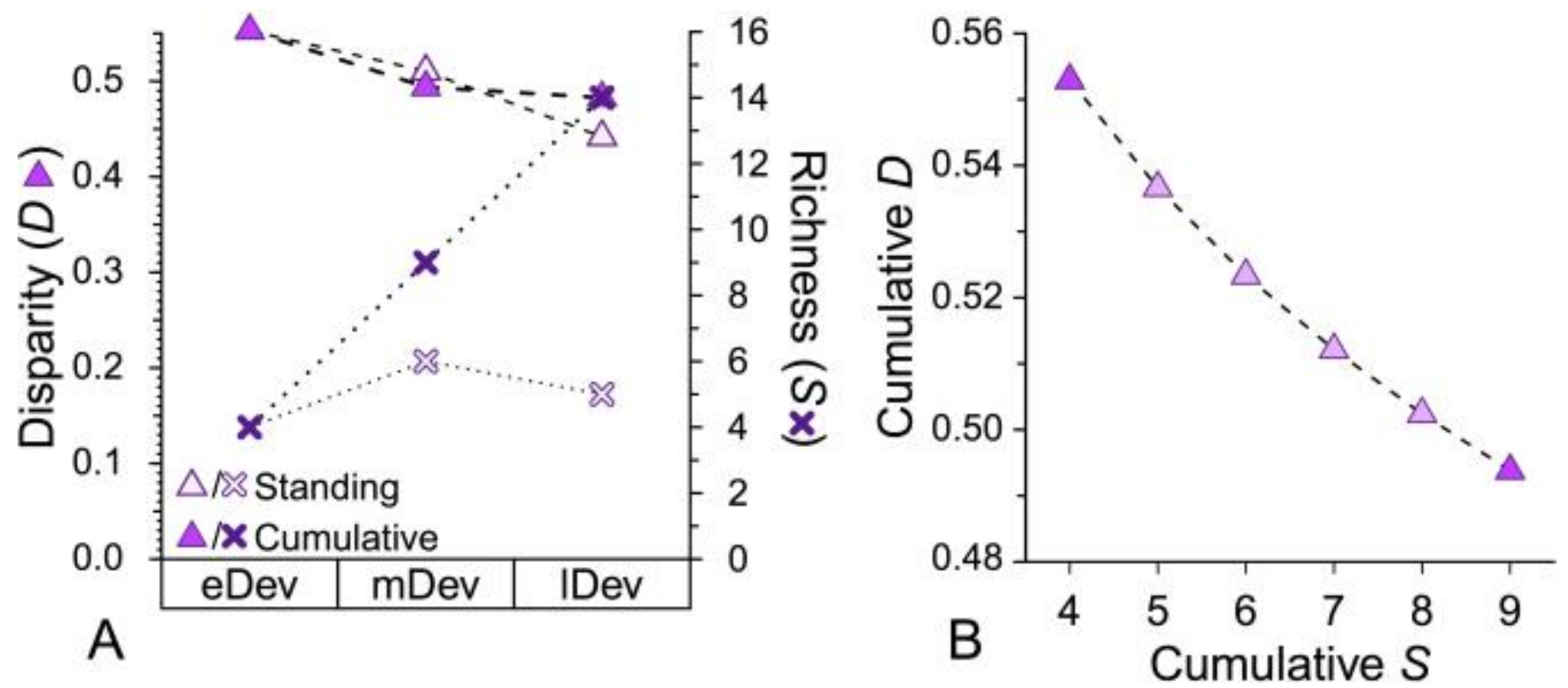

Fig. 1. Cumulative vs. standing disparity and richness for Floweria species. (A) Cumulative richness and disparity sum all species sampled through the Middle or Late Devonian, whereas standing richness and disparity reflect only species present at those times. (B) Interpolates the shift in disparity from the Early Devonian (i.e., the first 4 species) and the Middle Devonian (i.e., the first 9 species). The pale triangles give the estimated cumulative disparity assuming a linear increase change in disparity with an exponential change in richness. Finally, note that the actual midpoint here (and in all clades with even numbers of species) used is at $S=7.5$, as clade evolution starts at $S=1$.

average number of novel (derived) states per character (Lupia 1999). This also means that simply adding new combinations and "filling" morphospace can decrease disparity. Analyses calculate disparity among all $S$ taxa and for the earliest $S / 2$ taxa (Wagner and Estabrook 2014) see (Table 2 and Fig. 1). Analyses using the earliest $S / 3$ taxa are presented in the supplementary material. Using all taxa rather than standing diversity removes the effects of differential extinction or active trends on disparity patterns. When there are an odd number of taxa, I round up (e.g., the first seven taxa given either 13 or 14 total taxa). In cases where stratigraphic binning creates "ties" for taxon $S / 2$, the taxa creating the least disparity among the first $S / 2$ are chosen. So, if there are 21 taxa, and species 9, 10, 11 and 12 all appear in the same interval, whichever three of those species add least to total disparity are used along with taxa 1-8.

Early bursts are measured as the how many times greater (or less) observed disparity is among the first $S / 2$ taxa and expected disparity among those taxa given the Monte Carlo tests described below. Note that this is atypical of paleontological studies: usually disparity is measured solely given contemporaneous (or roughly contemporaneous) taxa (Foote 1991, 1992, 1993a, Hughes et al. 2013). Instead, it is closer to studies contrasting relative diversity among whole subclades (Foote 1993b, Wagner 1997). It also is akin to studies looking at the disparity 
Taxon F. be. F. de. F. pa. F. pe. F. an. F. ar. F. co. F. cr. F. li. F. ch. F. io. F. ma. F. pr. F. tr. \begin{tabular}{lllll|lllllllllllll}
\hline F. be. & $\bullet$ & 0.520 & 0.643 & 0.536 & 0.536 & 0.464 & 0.375 & 0.375 & 0.583 & 0.464 & 0.444 & 0.583 & 0.500 & 0.542
\end{tabular} $\begin{array}{lllllllllllllllll}\text { F. de. } 0.520 & \bullet & 0.720 & 0.720 & 0.240 & 0.640 & 0.208 & 0.500 & 0.208 & 0.400 & 0.417 & 0.667 & 0.400 & 0.500\end{array}$ $\begin{array}{llllllllllllllllll}\text { F. pa. } & 0.643 & 0.720 & \bullet & 0.179 & 0.571 & 0.321 & 0.750 & 0.625 & 0.708 & 0.464 & 0.556 & 0.333 & 0.607 & 0.458\end{array}$ $\begin{array}{llllllllllllllll}\text { F.per. } 0.536 & 0.720 & 0.179 & \bullet & & 0.536 & 0.393 & 0.708 & 0.667 & 0.667 & 0.429 & 0.556 & 0.375 & 0.643 & 0.500\end{array}$ $\begin{array}{llllllllllllllll}\text { F. an. } 0.536 & 0.240 & 0.571 & 0.536 & \bullet & 0.643 & 0.292 & 0.542 & 0.250 & 0.321 & 0.296 & 0.625 & 0.321 & 0.542\end{array}$

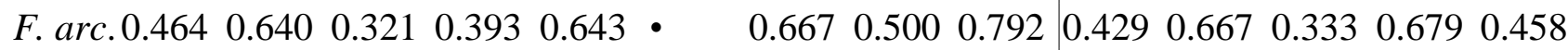
$\begin{array}{lllllllllllllllll}\text { F. co. } & 0.375 & 0.208 & 0.750 & 0.708 & 0.292 & 0.667 & \bullet & 0.333 & 0.208 & 0.458 & 0.208 & 0.708 & 0.208 & 0.500\end{array}$ $\begin{array}{lllllllllllllllllll}\text { F. cr. } & 0.375 & 0.500 & 0.625 & 0.667 & 0.542 & 0.500 & 0.333 & \bullet & 0.458 & 0.458 & 0.375 & 0.625 & 0.458 & 0.583\end{array}$ $\begin{array}{lllllllllllllllll}\text { F. li. } & 0.583 & 0.208 & 0.708 & 0.667 & 0.250 & 0.792 & 0.208 & 0.458 & \bullet & & 0.417 & 0.333 & 0.708 & 0.333 & 0.542\end{array}$ $\begin{array}{lllllllllllllllllllll}\text { F. ch. } & 0.464 & 0.400 & 0.464 & 0.429 & 0.321 & 0.429 & 0.458 & 0.458 & 0.417 & \bullet & 0.481 & 0.375 & 0.571 & 0.458\end{array}$ $\begin{array}{lllllllllllllllll}\text { F. io. } & 0.444 & 0.417 & 0.556 & 0.556 & 0.296 & 0.667 & 0.208 & 0.375 & 0.333 & 0.481 & \bullet & 0.667 & 0.074 & 0.458\end{array}$ $\begin{array}{lllllllllllllll}\text { F. ma. } 0.583 & 0.667 & 0.333 & 0.375 & 0.625 & 0.333 & 0.708 & 0.625 & 0.708 & 0.375 & 0.667 & \bullet & 0.667 & 0.208\end{array}$ $\begin{array}{llllllllllllllll}\text { F.pr. } & 0.500 & 0.400 & 0.607 & 0.643 & 0.321 & 0.679 & 0.208 & 0.458 & 0.333 & 0.571 & 0.074 & 0.667 & \bullet & 0.458\end{array}$ $\begin{array}{lllllllllllllllll}\text { F. tr. } & 0.542 & 0.500 & 0.458 & 0.500 & 0.542 & 0.458 & 0.500 & 0.583 & 0.542 & 0.458 & 0.458 & 0.208 & 0.458 & \bullet\end{array}$

Table 2. Pairwise dissimilarities among Devonian Floweria species. F. be $=$ Floweria becraftensis; $F$. de. $=F$. deformis $F$. pa. $=F$. pandora $F$. pe. $=F$. perversa $F$. an. $=F$. anomala $F$. ar. $=F$. arctostriata $F$. $c o=F$. cornucopia $; F . c r .=F$. crassa $F$. li. $=F$. lirella $F$. ch. $=F$. chemungensis $; F$. io. $=F$. iowensis $F$. ma. $=F$. magnacicatrix $F . p r .=F$. prava $F . t r .=F$. transversalis. Numbers give pairwise dissimilarity between species, i.e. the number differing characters divided by the number of characters for which both species are coded. This is done after polymorphic characters are fixed to the state maximizing stratigraphic compatibility. Cumulative disparity is estimated from the average pairwise dissimilarity among: 1) $F$. becraftensis $-F$. perversa (the four early Devonian species); 2) F. becraftensis $-F$. lirella (the nine early-middle Devonian species); and, 3) F. becraftensis $-F$. transversalis (the 14 total species). Note that $F$. perversa survives into the Middle Devonian. The final number gives the cumulative disparity for all 14 species. The disparity for the first 7.5 species (i.e., the first half of Floweria evolution) is interpolated from the first and second numbers assuming a linear change in disparity with a logarithmic change in richness. See Fig. 1.

encompassed by whole clades within phylogenies of extant taxa (Harmon et al. 2010, Rabosky et al. 2013).

\section{Measuring compatibility and stratigraphic compatibility}

Compatible characters have 3 of 4 possible combinations if the characters are binary (e.g., 00, 10 and 01) (Le Quesne 1969, Estabrook et al. 1975). Multistate characters are considered unordered; compatibility reflects whether all binary breakdowns have three or fewer combinations as well as whether the collection of state-pairs demands parallelism or reversal (Estabrook et al. 1975, Wagner and Estabrook 2014). Note that treating multistate characters as unordered maximizes their compatibility as combinations that are considered compatible given unordered change are considered incompatible given ordered change because some parallel "decrease" or "increase" is invoked even if the final combination of character states is unique (Meacham 1984, Salisbury 1999, Hoyal Cuthill 2015). As 
frequencies of homoplasy (i.e., reversals or parallelisms) increase, compatibility decreases.

Stratigraphic compatibility represents compatible character pairs in which each combination of characters appears in the fossil record in an order consistent with a simple character state tree (Estabrook and McMorris 2006). For the set 00, 10 and 01, this requires that oldest species bearing $\mathbf{0 0}$ occurs in older strata than the oldest species bearing 10 and/or 01 . If the oldest species with the intermediate character pair is older than (or as old as) either of those other two species, then the fossil record is consistent with simple trees positing no homoplasy and no basic gaps in the fossil record. Because stratigraphic compatibility utilizes only compatible characters, it is uncorrelated with frequencies of homoplasy. Because compatible characters are based on rates of change relative to rates of taxon sampling, stratigraphic compatibility also is uncorrelated with per-lineage sampling intensity (Wagner and Estabrook 2015). Instead, the two primary models decreasing stratigraphic compatibility are elevated rates of early change and correlated change followed by independent change (Wagner and Estabrook 2015).

\section{Monte Carlo tests estimating independent change rates using character compatibility}

For $S$ taxa with $N$ characters, there will be some range of changes ("steps") that maximize the probability of observed compatibility and the observed number of novel states assuming independent change (O'Keefe and Wagner 2001, Wagner 2012, Wagner and Estabrook 2015). This is assessed using Monte Carlo analyses that simulate phylogenies of $S$ taxa (= number of sampled ingroup taxa) using rates of cladogenesis, extinction and sampling appropriate to each analyzed clade (Wagner and Estabrook 2014, 2015). The analyses evolve one step at a time over $N$ characters (= variable fossilizable characters in the original dataset) and track the average compatibility at X steps in order to estimate the likelihood of $\mathrm{X}$ steps given observed compatibility. The probability of any individual character changing is uniform, as this adds a conservative bias to the analyses by making it easier to derive each state with the minimum steps necessary (Wagner et al. 2006) and thus maximizes the likely compatibility associated with $N$ novel states. Character state evolution also is unordered, as this minimizes the expected number of changes needed to evolve all $N$ states in an $N$-state character (Foote 1994, Wagner 2000b), and thus maximizes the likely compatibility associated with the whole character space. These analyses are repeated 1000 times to find the $\mathrm{X}$ maximizing the probability of observed compatibility is used for the uniform (1-rate) model of change. This is repeated using the earliest $S / 2$ (or $S / 3$ ) taxa, where the "first" $S / 2$ (or $S / 3$ ) taxa always are the same as for the disparity analyses. Now $\mathrm{X}$ is found that 
simultaneously maximizes the probability of the observed compatibility given only the earliest taxa and the probability of having as many derived character states as actually observed among the earliest taxa.

Although it is possible to model modules of integrated characters, even simple models involve many more than two varying parameters (Gerber et al. 2011). Moreover, because the number of characters per module and the number of modules with a collection of characters all can vary, this rapidly becomes unfeasible when evaluating large numbers of datasets. Because we expect stratigraphic compatibility to drop precipitously in the presence of integration/modularity reorganization, correlations between stratigraphic compatibility and disparity are used instead of inverse modeling of integration/modularity reorganization.

\section{Monte Carlo analyses for expected early disparity and stratigraphic compatibility}

The most likely whole-clade (1-rate) and early vs. late (2-rate) models of independent change from the first set of Monte Carlo analyses then are used in a second set of Monte Carlo analyses that tally disparity among the first $S / 2$ (or $S / 3$ ) as a proportion of disparity among all $S$ taxa given either the 1-rate or 2-rate models of independent change. These same analyses also are used to estimate expected stratigraphic compatibility. The simulations assume budding cladogenesis, in which ancestral morphospecies persist after speciation and can give rise to any number of descendants (Raup and Gould 1974), rather than bifurcating cladogenesis, in which ancestors become pseudo-extinct upon branching and thus give rise to only 2 descendants (Slowinski and Guyer 1989). The simulations also assume exponential growth. Neither has any effect on disparity as calculated here, but budding and exponential models both generate lower stratigraphic compatibility than do bifurcating and richness-dependent diversification models such as logistic (Sepkoski 1979) or hierarchical (Brayard et al. 2009) models (Wagner and Estabrook 2015). The simulations again assume unordered character state change for multistate characters, which again maximizes both expected disparity and expected compatibility at X steps. As before, evolutionary and sampling parameters appropriate to each clade are used (Wagner and Estabrook 2014, 2015). 

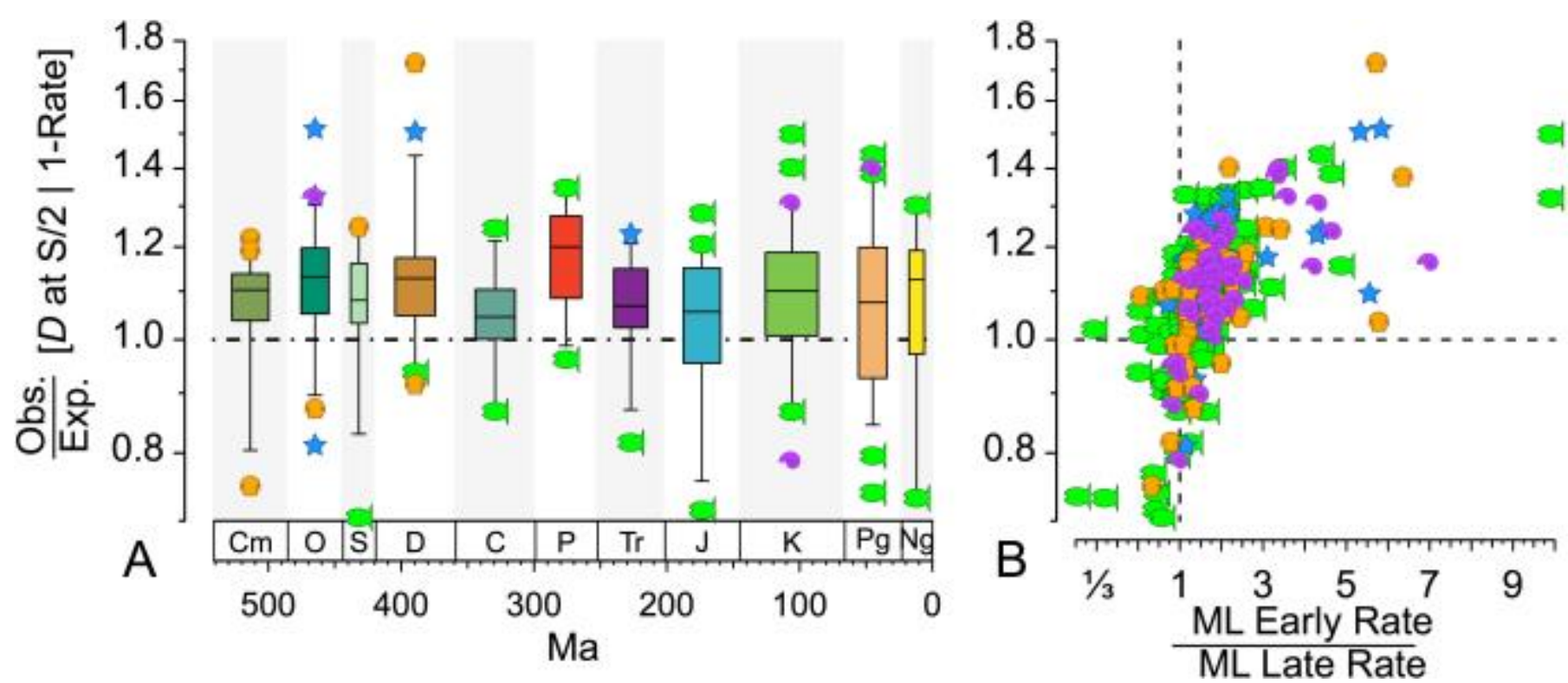

Fig. 2. Deviations from expected disparity $(D)$ among the first $S / 2$ of $S$ taxa given the uniform rates of independent change that maximize the probability of observed compatibility. Deviations are on a log-scale so that one-half and twice of expected $D$ represent the same absolute deviation. (A) Deviations over time. $\tau=-0.039, p=0.379$. (B) Deviations against the ratio between early and late rates maximizing the probability of compatibility among the first S/2 taxa. Molluscs+Brachiopods (purple shells): $\tau=0.383$, $p=1.0 \times 10^{-4}$; Arthropods (orange trilobites): $\tau=0.443, p=4.6 \times 10^{-6}$; Echinoderms (blue stars): $\tau=0.411$, $\mathrm{p}=2.0 \times 10^{-4}$; Chordates (green fishes): $\tau=0.488, p=3.6 \times 10^{-15}$.

The analyses use 1000 simulations for both rate models. Each run calculates disparity at $S / 2$ (or $S / 3$ ) using the same criteria as used for the original data. The median disparity at $S / 2$ (or $S / 3$ ) taxa from those 1000 replicates is used for the expected early disparity given the 1-rate or 2-rate model. The median stratigraphic compatibility at $S / 2$ (or $S / 3$ ) from the analyses using the 2-rate model is used for the expected stratigraphic compatibility. Analyses were conducted using programs written in C that are available at http://dx.doi.org/10.5061/dryad.h5971.

Wilcoxan signed rank tests, a nonparametric analog of the t-test, assess whether deviations from expected early disparity are biased in favor of more and/or larger early bursts (excess positive ranks) or delayed bursts (excess negative ranks). Because the tests use ratios of observed to expected, the ratios are log-transformed so that early disparity 1.5 times expected has the same absolute rank as early disparity 0.67 times expected. Thus, any positive deviation can have an identically ranked negative deviation. Kendall's rank correlation tests are used to assess correlations between the ratios of observed and expected early disparity with time, early rates and stratigraphic compatibility.

\section{Results}

Early bursts of disparity exceeding expectations given character compatibility and uniform frequencies of change (i.e., the exhaustion model) occur in 203 of the 257 

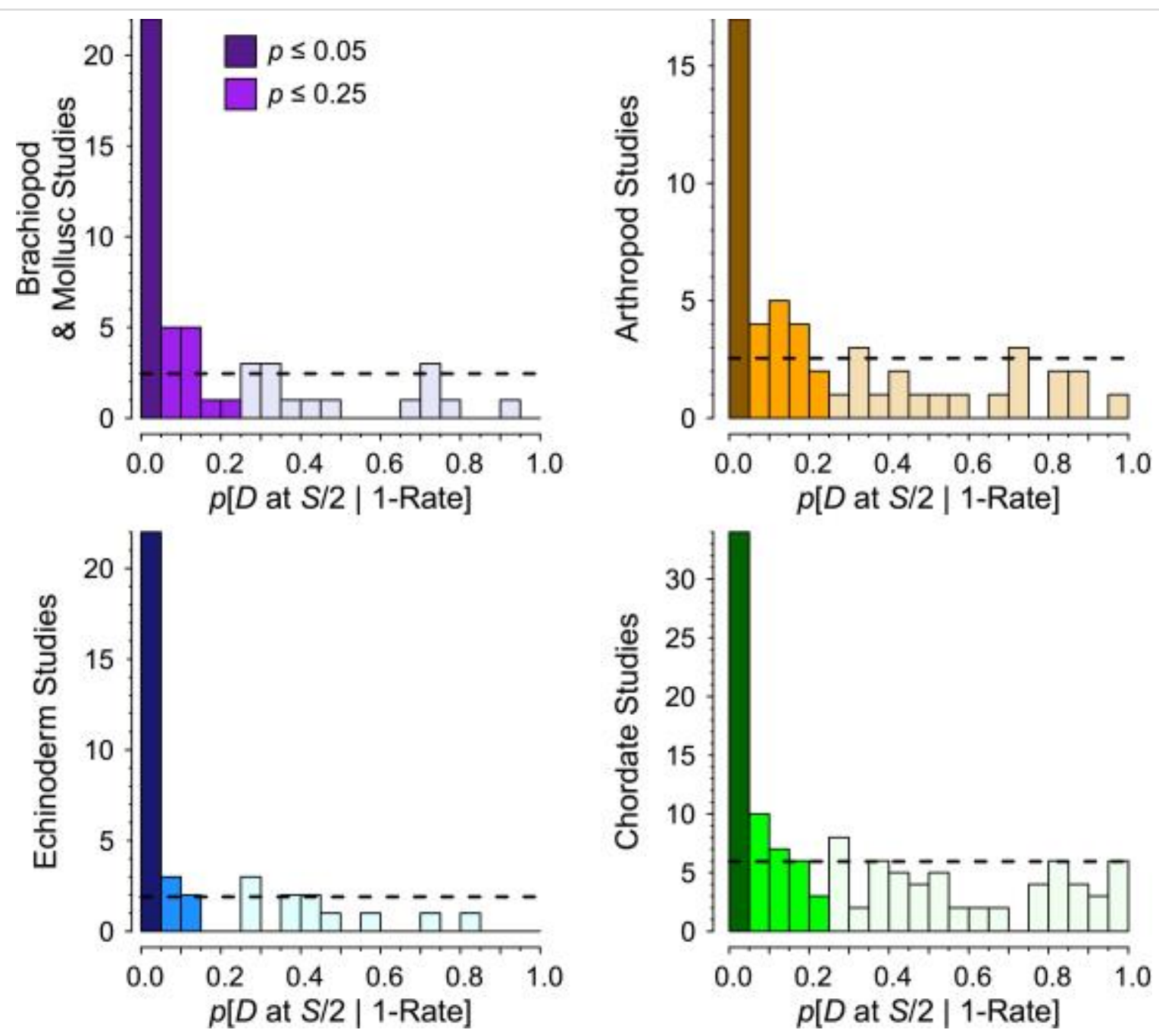

Fig. 3. Probabilities of observed disparity $(D)$ accumulated during the first half of clade evolution $(S / 2)$ given the best-fit uniform rate of independent change for all $S$ taxa in each clade. Significance based on 1000 Monte Carlo replications. Best-fit uniform rates maximize the probability of observed character compatibility for all $S$ taxa. Dashed lines show the expected number of studies at each $p$-value.

clades examined (Fig. 2A). Many of the deviations are quite large: in 91 cases, the deviations are significant at $p \leq 0.05$ (Fig. 3). Within each of brachiopods+molluscs, arthropods, echinoderms and chordates, significantly more than half of studies show excess early disparity (Table 3). The summed ranks of absolute deviations (log-transformed so that one half and twice expected disparity have the same absolute rank) is significantly biased towards excess early disparity. The pattern also is common throughout the Phanerozoic: significantly more clades than half of studies show excess early disparity in 8 of 11 periods, and the summed ranks are biased significantly in favor of excess early disparity in 9 of 11 periods (Table 4). Differences between observed and expected disparity given the exhaustion model correlate with the relative difference between early rates and late rates from 2-rate 
Table 3. Deviations from expected early disparity within major taxonomic groups. "Studies" refers to the number of published matrices represent clades used. "Excess" gives the number of studies with excess disparity in the first half of clade evolution given a single rate ("1-Rate") and given separate early and late rates ("2-Rates"), with the early rate maximizing the probability of character compatibility given the earliest $S / 2$ of $S$ total taxa. The significance is the binomial probability of that many excess cases given the total studies and an expectation of $50 \%$. " $\sum R$ " gives the signed rank statistic, which ranks deviations by absolute values but then gives each rank $\mathrm{a}+/$ - based on the original statistic. Deviations are ranked after log-transformation, so half the expected disparity has the same rank as twice the expected disparity. Significance is assessed on the expectation that $\sum R=0$.

\begin{tabular}{lcccccccccc} 
& \multicolumn{1}{c}{ 1-Rate } & \multicolumn{2}{c}{ 1-Rate } & \multicolumn{2}{c}{ 2-Rates } & \multicolumn{2}{c}{ 2-Rates } \\
\hline Taxa & Studies & Excess & $p$ & $\sum R$ & $p$ & Excess & $p$ & $\sum R$ & $p$ \\
\hline Brachiopods & & & & & & & & & \\
$\quad+$ Molluscs & 49 & 43 & $7.6 \times 10^{-9}$ & 989 & $4.4 \times 10^{-7}$ & 35 & $1.4 \times 10^{-3}$ & 749 & $9.8 \times 10^{-5}$ \\
Arthropods & 51 & 40 & $1.5 \times 10^{-5}$ & 872 & $2.2 \times 10^{-5}$ & 33 & 0.024 & 570 & $3.8 \times 10^{-3}$ \\
Echinoderms & 38 & 35 & $5.4 \times 10^{-9}$ & 653 & $1.1 \times 10^{-6}$ & 28 & $1.7 \times 10^{-3}$ & 525 & $7.0 \times 10^{-5}$ \\
Chordates & 119 & 85 & $1.3 \times 10^{-6}$ & 3441 & $1.9 \times 10^{-6}$ & 78 & $2.9 \times 10^{-4}$ & 2222 & $1.6 \times 10^{-3}$
\end{tabular}

models for each clade (Fig. $2 \mathbf{2 B} ; \tau=0.470 ; p<10^{-20}$ ). This association is significant within all four general taxonomic partitions. The associations between early bursts and best-fit early rates are positive in all 11 periods, and significant at $p \leq 0.06$ in 9 of 11 periods. Thus, both disparity and compatibility patterns deviate from the expectations of the exhaustion model.
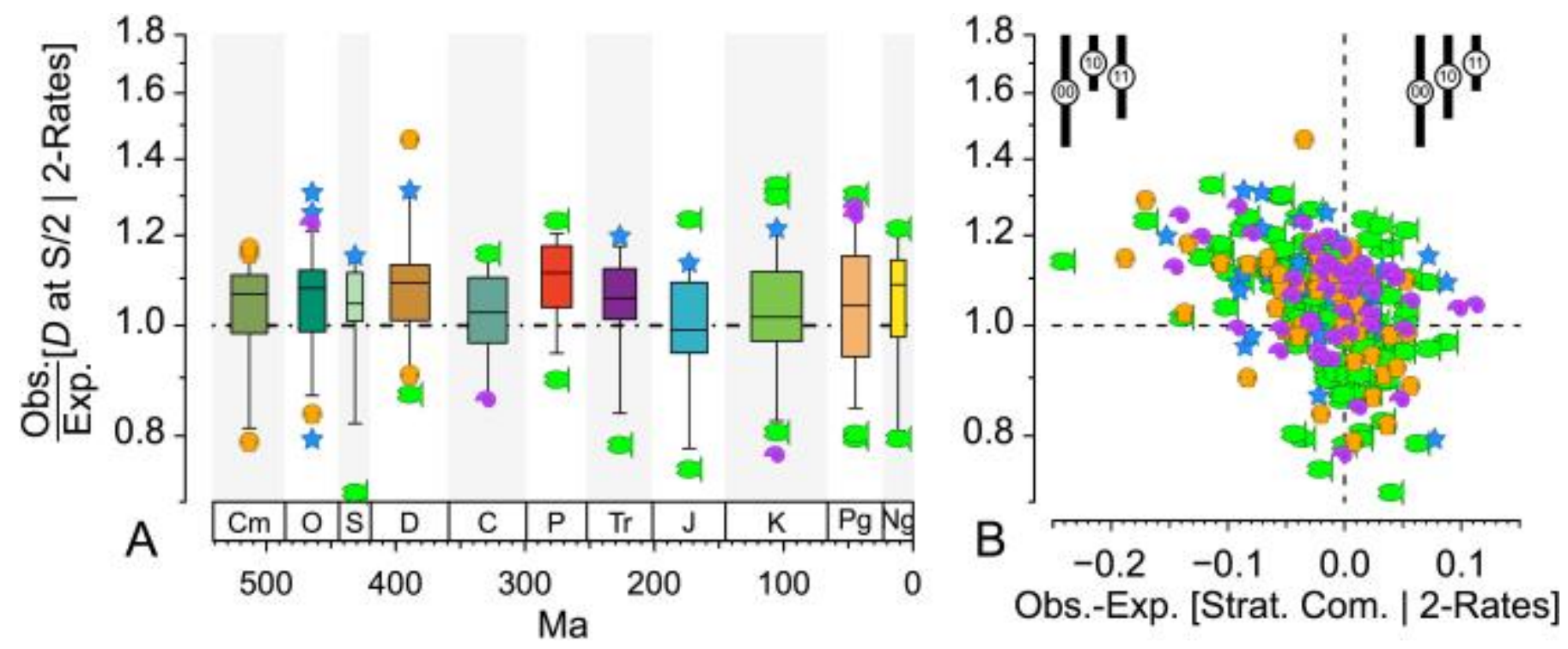

Fig. 4. Deviations from expected disparity $(D)$ among the first $S / 2$ of $S$ taxa given the early rates of independent change that maximize the probability of observed compatibility among the first $S / 2$ taxa. See Fig. 1 for further details. (A) Deviations over time. $\tau=-0.035, p=0.421$. (B) Disparity deviations against deviations from expected stratigraphic compatibility given the same 2-rate model. Molluscs+Brachiopods (purple shells): $\tau=-0.191, p=0.053$; Arthropods (orange trilobites): $\tau=-0.343, p=3.9 \times 10^{-4}$; Echinoderms

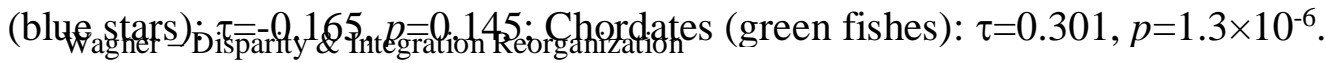

Page $\mathbf{1 1}$ of $\mathbf{5 6}$ 
Table 4. Deviations from expected early disparity over time. "Periods" give geochronological periods of the plurality of taxa within any one clade. See Table 3 for further details.

\begin{tabular}{lcrlrlrlrl} 
& \multicolumn{4}{c}{ 1-Rate } & \multicolumn{2}{c}{ 1-Rate } & \multicolumn{2}{c}{ 2-Rates } & \multicolumn{2}{c}{ 2-Rates } \\
\hline Period & Studies & Excess & $p$ & $\sum R$ & $p$ & Excess & $p$ & $\sum R$ & $p$ \\
\hline Cambrian & 21 & 17 & $3.6 \times 10^{-3}$ & 131 & 0.011 & 14 & 0.095 & 95 & 0.049 \\
Ordovician & 42 & 36 & $1.4 \times 10^{-6}$ & 731 & $2.4 \times 10^{-6}$ & 31 & $1.4 \times 10^{-3}$ & 533 & $4.3 \times 10^{-4}$ \\
Silurian & 14 & 11 & 0.029 & 67 & 0.018 & 11 & 0.029 & 51 & 0.055 \\
Devonian & 29 & 26 & $7.6 \times 10^{-6}$ & 395 & $9.7 \times 10^{-6}$ & 22 & $4.1 \times 10^{-3}$ & 313 & $3.6 \times 10^{-4}$ \\
Carboniferous & 12 & 9 & 0.073 & 32 & 0.105 & 8 & 0.194 & 18 & 0.240 \\
Permian & 11 & 10 & $5.9 \times 10^{-3}$ & 62 & $2.9 \times 10^{-3}$ & 10 & $5.9 \times 10^{-3}$ & 54 & $8.2 \times 10^{-3}$ \\
Triassic & 16 & 13 & 0.011 & 70 & 0.035 & 12 & 0.038 & 60 & 0.060 \\
Jurassic & 21 & 14 & 0.095 & 85 & 0.070 & 10 & 0.500 & 25 & 0.332 \\
Cretaceous & 38 & 30 & $2.4 \times 10^{-4}$ & 509 & $6.2 \times 10^{-5}$ & 22 & 0.209 & 229 & 0.048 \\
Paleogene & 41 & 28 & 0.014 & 427 & $2.8 \times 10^{-3}$ & 25 & 0.106 & 267 & 0.042 \\
Neogene & 12 & 9 & 0.073 & 30 & 0.136 & 9 & 0.073 & 28 & 0.120
\end{tabular}

Early bursts of disparity exceed expectations given separate early/late frequencies of change in 174 of 257 clades (Fig. 4A). In 40 cases, the deviations are significant at $p \leq 0.05$ (Fig. 5). Excess early disparity deviates significantly from the expectations of best-fit single-rate models within the basic taxonomic partitions (Table 3). In every period but the Jurassic, over half of the clades show greater disparity than predicted by elevated early rates, with five periods showing deviations significant at $p \leq 0.05$ (Table 4). All 11 periods have ranked absolute deviations favoring positive (excess) disparity, with 8 of 11 periods deviating from a symmetrical distribution around zero at $p \leq 0.06$. Thus, early bursts of disparity typically exceed the expectations of plausible elevated early rates of independent change (Table 1).

Disparity exceeding 2-rate independent change models correlates negatively with stratigraphic compatibility within clades (Fig. $2 \mathrm{~B} ; \tau=-0.277 ; p=1.7 \times 10^{-10}$ ). This association exists in all 11 periods, although it is rarely significant (Table 4). The associations also are negative in all four higher taxonomic partitions (Table 2) and significant at $p \leq 0.05$ for all groups save echinoderms. Thus, as predicted by the integration/modularity reorganization models, early bursts of disparity deviating further from the expectations of independent character change correspond to a greater tendency for compatible sets of character pairs to appear out of order in the fossil record.

\section{Discussion}

There are many reasons to think that these results are conservative. One, Monte Carlo tests looking at disparity and rate shifts among the earliest $S / 3$ taxa generate 

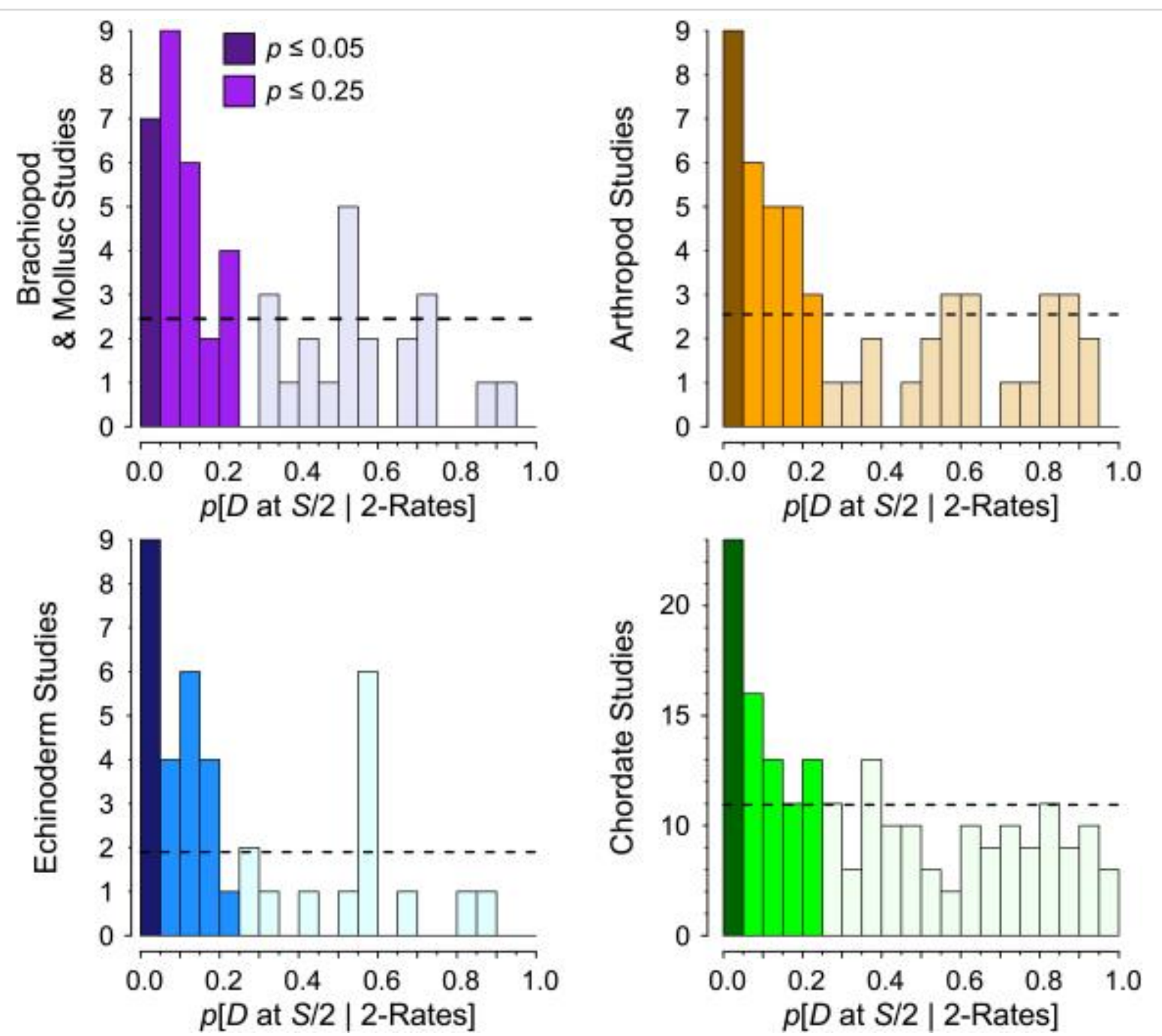

Fig. 5. Probabilities of observed disparity $(D)$ accumulated during the first half of clade evolution ( $S / 2)$ given the best-fit "early" and "late" rates of independent change. See Fig. 3 for further details.

nearly identical results (Table S1-2, Figs. S1-S4). This indicates that the early bursts are concentrated even earlier in clade histories than simply anytime in the first half. Two, the evolutionary models used by the Monte Carlo tests (see Methods) were chosen to minimize expected stratigraphic compatibility (Wagner and Estabrook 2015), and thus minimize any association between excess stratigraphic incompatibility and excess disparity. Three, although there is copious evidence for rate heterogeneity among characters (Wagner 2012; Harrison and Larsson 2015), these tests assume homogeneous rates among characters. Homogeneous rates minimize the expected number of changes (and thus maximize the possible compatibility) necessary to evolve numerous derived states. This exaggerates how easily both high disparity and high compatibility are evolved simultaneously. Four, the analyses attribute as much disparity as possible to 2-rate 
independent change models before considering the predictions of the integration/modularity reorganization model. Thus, much of the change that the integration/modularity reorganization model would generate is attributed to elevated independent change. Five, systematists are counseled to exclude characters that might be correlated with other characters (Patterson 1982). The low levels of stratigraphic incompatibility argue that systematists are not completely successful at doing this, but the practice still biases these data against corroborating hypotheses invoking correlated change.

Other explanations also fail to account for the results. For example, low sampling of early taxa might elevate early disparity (Foote 1996a). However, there is no reason to think that per-taxon sampling typically is low early in clade histories. Moreover, paleontologists often target early members of clades for phylogenetic studies out of concern that parallelisms and reversals among later taxa will distort basic relationships (Smith 2001). Regardless, the 2-rate models double as low early sampling models (Wagner and Estabrook 2015): one way to get separate early per-branch rates of change is to have different early sampling rates that mean fewer (or more) unsampled ancestors exist along each branch (Foote et al. 1999; Wagner 2000a). Thus, disparity exceeding the 2-rate models and the correlation of this excess disparity with stratigraphic compatibility demand explanations other than sampling.

These results corroborate other meta-analyses showing that early bursts are common in paleontological data (Hughes et al. 2013). However, because this study uses cumulative disparity rather than contemporaneous disparity, these results cannot be attributed to high early taxonomic richness (see Foote 1996a). By establishing expected disparity through character compatibility, these results also show that early bursts are not driven by exhaustion of character states. Finally, the results indicate early bursts often are more than just elevated rates of independent character change: too often, the numbers of independent changes needed to generate the early disparity should also precipitate many more reversals and parallelisms than the observed character compatibility among early taxa allows. Correlated change associated with integration circumvents this by concentrating $N$ changes in $N$ characters, which maximizes disparity while retaining high character compatibility among characters within the altered suite (O'Keefe and Wagner 2001). Thus, correlated change within integrated modules allows both high disparity and high compatibility when independent change will not.

The integration/modularity reorganization model and the early bursts it induces is consistent the expected effects of Gene Regulatory Networks (Davidson and Erwin 
2006) and Character Identity Networks (Wagner 2007). The impetus would be the rare circumstance in which one or more novelties generated by change to a character complex is an innovation (Erwin 2012) that outweighs any maladaptive effects of changing other characters in the same complex (Davidson and Erwin 2010). In principle, this would introduce strong selection for reducing integration or other linkages among characters, i.e., parcellation (Wagner 1996), in the same module as the innovation(s) (Polly 1998), which in turn would allow other characters to either return to functionally superior primitive conditions (creating stratigraphic incompatibility) or develop still different states (creating further disparity). If the innovation (s) opens up new ecologic opportunities and/or alters functional interactions with characters in other modules, then the stage is set for selection favoring reorganization of integration among other character modules (Davidson and Erwin 2006, Goswami 2006, Davidson and Erwin 2010, Erwin 2012). This might also provide a link between elevated origination and elevated disparity/evolvability if the innovation(s) in question affect origination/extinction probabilities (Erwin 2012, Rabosky et al. 2013). Subsequent evolution of integration networks within the new modules would later diminish evolvability and discourage additional disparity.

An integration/modularity reorganization model further erodes the false dichotomy between "developmental constraints" and "ecological restrictions" (Erwin 2007). If unusual ecological opportunities help create circumstances where the benefits of one novelty or a few novelties outweigh the drawbacks of associated changes (Polly 1998), then parcellation of modules due ecological pressures and any variation in developmental parameters should alter the ease in which taxa can achieve different combinations of character states and different adaptive peaks (Marshall 2014). If so, then examination of individual clades might suggest ecological "cues" associated with increases in disparity and low stratigraphic compatibility (see Gerber 2013).

A question that might arise is: given that all early bursts are actually "delayed bursts" within a larger clade (Hopkins and Smith 2015), why does elevated disparity always occur early in our prior definitions of taxa? A simple explanation is that: 1) systematists choose groups of species for phylogenetic (or disparity) analyses based on prior higher taxonomic definitions; and, 2) prior higher taxonomic definitions are based on amounts of difference and apparent "gaps" in character space separating that cluster of species from other clusters of species. Gaps in character space subsequently recognized by taxonomists as distinguishing higher taxa would be side effect of correlated changes followed by reorganization of sets of integrated or otherwise linked characters. In other words, the evolvability 
and disparity accompanying integration/modularity reorganization produce the anatomical differences that systematists use to decide which taxa to include in phylogenetic analyses, and thus establishes the "early" portions of higher taxon histories (Davidson and Erwin 2006,2010).

\section{Conclusion}

We have long modeled early bursts using models assuming that individual characters had unusually high rates of evolution. Models concerning shifts intrinsic constraints and/or ecological limits simply assumed that these shifts depressed frequencies of independent change. However, these models are inadequate to explain the bursts of disparity and observed compatibility that we do see. Instead, the observed patterns are consistent with correlated change among suites of characters rapidly elevating disparity, with subsequent changes including not simply novel character states that further add to disparity, but uncoupling of existing linkages that allow for reversals to prior conditions. Thus, modeling expected morphological change early in the evolution of major groups should explicitly allow for not just elevated rates, but also correlated change followed by independent change in some suites of characters.

\section{References}

Abdala, F. 2007. Redescription of Platycraniellus elegans (Therapsida, Cynodontia) from the Lower Triassic of South Africa, and the cladistic relationships of eutheriodonts. Palaeontology 50:591 - 618.

Abdala, F., and A. M. Ribeiro. 2003. A new traversodontid cynodont from the Santa Maria Formation (Ladinian-Carnian) of southern Brazil, with a phylogenetic analysis of Gondwanan traversodontids. Zoological Journal of the Linnean Society 139:529 - 545.

Adrain, J. M. 1998. Systematics of the Acanthoparyphinae (Trilobita), with species from the Silurian of Arctic Canada. Journal of Paleontology 72:698 718.

Adrain, J. M., B. D. E. Chatterton, and G. J. Kloc. 2008. Systematics of the Koneprusiine trilobites, with new taxa from the Silurian and Devonian of Laurentia. Journal of Paleontology 82:657-675.

Adrain, J. M., and G. D. Edgecombe. 1997. Silurian (Wenlock) calymenid trilobites from the Cape Phillips Formation, Central Canadian Arctic. Journal of Paleontology 71:657 - 682.

Adrain, J. M., S. R. Westrop, E. Landing, and R. A. Fortey. 2001. Systematics of the Ordovician trilobites Ischyrotoma and Dimeropygiella, with species from the type Ibexian area, western U.S.A. Journal of Paleontology 75:947 - 971. 
Ahlberg, P. E., J. A. Clack, E. Luksevics, H. Blom, and I. Zupins. 2008. Ventastega curonica and the origin of tetrapod morphology. Nature 453:11991204.

Alroy, J. 1995. Continuous track analysis: a new phylogenetic and biogeographic method. Systematic Biology 44:152 - 178.

Amati, L., R. M. Feldmann, and J.-P. Zonneveld. 2004. A new family of Triassic lobsters (Decapoda: Astacidea) from British Columbia and its phylogenetic context. Journal of Paleontology 78:150-168.

Amati, L., and S. R. Westrop. 2004. A systematic revision of Thaleops (Trilobita: Illaenidae) with new species from the Middle and Late Ordovician of Oklahoma and New York. Journal of Systematic Palaeontology 2:207-256.

Andres, B., J. M. Clark, and X. Xing. 2010. A new rhamphorhynchid pterosaur from the Upper Jurassic of Xinjiang, China, and the phylogenetic relationships of basal pterosaurs. Journal of Vertebrate Paleontology 30:163 - 187.

Angielczyk, K. D. 2002. Redescription, phylogenetic position, and stratigraphic significance of the dicynodont genus Odontocyclops (Synapsida:

Anomodontia). Journal of Paleontology 76:1047 - 1059.

"Cryptocynodon parringtoni" von Huene, 1942 (Therapsida, Anomodontia), with an expanded analysis of Permian dicynodont phylogeny. Journal of Vertebrate Paleontology 27:116 - 131.

Archibald, J. D., A. O. Averianov, and E. G. Ekdale. 2001. Late Cretaceous relatives of rabbits, rodents, and other extant eutherian mammals. Nature 414:62-65.

Arratia, G. 1996. Reassessment of the phylogenetic relationships of certain Jurassic teleosts and their implications on teleostean phylogeny. Pp. 219 - 242 in G. Arratia and G. Viohl, eds. Mesozoic Fishes - Systematics and Paleoecology. Verlag, München.

Arratia, G., and H. Tischlinger. 2010. The first record of Late Jurassic crossognathiform fishes from Europe and their phylogenetic importance for teleostean phylogeny. Fossil Record 13:317-341.

Ausich, W. I. 1998a. Early phylogeny and subclass division of the Crinoidea (Phylum Echinodermata). Journal of Paleontology 72:499 - 510.

Echinodermata) and suprageneric classification of the Crinoidea. The University of Kansas Paleontological Contributions 9:1 - 36.

Ausich, W. I., and T. W. Kammer. 2008. Evolution and extinction of a Paleozoic crinoid clade: phylogenetics, paleogeography, and environmental distribution of the periechocrinids. Pp. 145 - 171 in W. I. Ausich and G. D. Webster, eds. Echinoderm paleobiology. Indiana University Press, Bloomington. 
Babcock, L. E. 1994. Systematics and phylogenetics of polymeroid trilobites from the Henson Gletscher and Kap Stanton Formations (Middle Cambrian), North Greenland. Grønlands Geologiske Undersøgelse Bulletin 169:79 - 127. Barras, C. G. 2007. Phylogeny of the Jurassic to Early Cretaceous 'disasteroid' echinoids (Echinoidea; Echinodermata) and the origins of spatangoids and holasteroids. Journal of Systematic Palaeontology 5:133 - 161.

Bell, G. L., Jr. 1997. A phylogenetic revision of North American and Adriatic Mosasauroidea. Pp. 293 - 332 in J. M. Callaway and E. L. Nicholls, eds. Ancient marine reptiles. Academic Press, San Diego.

Benedetto, J. 2009. Chaniella a new lower Tremadocian (Ordovician) brachiopod from northwestern Argentina and its phylogenetic relationships within basal rhynchonelliforms. Paläontologische Zeitschrift 83:393-405.

Benson, R., M. Carrano, and S. Brusatte. 2010. A new clade of archaic largebodied predatory dinosaurs (Theropoda: Allosauroidea) that survived to the latest Mesozoic. Naturwissenschaften 97:71-78.

Benson, R. B. J. 2012. Interrelationships of basal synapsids: cranial and postcranial morphological partitions suggest different topologies. Journal of Systematic Palaeontology 10:601-624.

Bentley, C. J., and J. B. Jago. 2004. Wuaniid trilobites of Australia. Memoirs of the Association of Australasian Palaeontologists 30:179 - 191.

Bisconti, M. 2007. A new basal balaenopterid whale from the Pliocene of northern Italy. Palaeontology 50:1103 - 1122.

Blake, D. B. 2010. Comptoniaster adamsi nov. sp. (Echinodermata, Asteroidea) from the middle Cretaceous of Texas and its phylogenetic position. Geobios 43:179-190.

Bloch, J. I., D. C. Fisher, K. D. Rose, and P. D. Gingerich. 2001. Stratocladistic analysis of Paleocene Carpolestidae (Mammalia, Plesiadapiformes) with description of a new late Tiffanian genus. Journal of Vertebrate Paleontology 21:119-131.

Bodenbender, B. E. 1995. Morphological, crystallographic, and stratigraphic data in cladistic analyses of blastoid phylogeny. Contributions from the Museum of Paleontology, the University of Michigan 29:201 - 257.

Boisserie, J.-R. 2005. The phylogeny and taxonomy of Hippopotamidae (Mammalia: Artiodactyla): a review based on morphology and cladistic analysis. Zoological Journal of the Linnean Society 143:1 - 26.

Botha, J., F. Abdala, and R. Smith. 2007. The oldest cynodont: new clues on the origin and early diversification of the Cynodontia. Zoological Journal of the Linnean Society 149:477-492. 
Brayard, A., G. Escarguel, H. Bucher, C. Monnet, T. Bruhwiler, N. Goudemand, T. Galfetti, and J. Guex. 2009. Good genes and good luck: ammonoid diversity and the End-Permian Mass Extinction. Science 325:1118 - 1121.

Brezinski, D. K. 2003. Evolutionary and biogeographical implications of phylogenetic analysis of the Late Palaeozoic trilobite Paladin. Special Papers in Palaeontology 70:363 - 375.

. 2005. Paleobiogeographic patterns in Late Mississippian trilobites of the United States with new species from Montana. Annals of the Carnegie Museum 74:77 - 89.

Brochu, C. A. 1997. Morphology, fossils, divergence timing, and the phylogenetic relationships of Gavialis. Systematic Biology 46:479 - 522.

Brower, J. C. 2001. Flexible crinoids from the Upper Ordovician Maquoketa formation of the northern midcontinent and the evolution of early flexible crinoids. Journal of Paleontology 75:370 - 382.

Brusatte, S. L., M. J. Benton, J. B. Desojo, and M. C. Langer. 2010a. The higherlevel phylogeny of Archosauria (Tetrapoda: Diapsida). Journal of Systematic Palaeontology 8:3 - 47.

Brusatte, S. L., M. A. Norell, T. D. Carr, G. M. Erickson, J. R. Hutchinson, A. M. Balanoff, G. S. Bever, J. N. Choiniere, P. J. Makovicky, and X. Xu. 2010 b. Tyrannosaur paleobiology: new research on ancient exemplar organisms. Science 329:1481-1485.

Campbell, M. J., and B. D. E. Chatterton. 2007. Late Ordovician and Silurian lichid trilobites from Northwestern Canada: Hemiarges, Borealarges, and Richterarges. Journal of Paleontology 81:1348 - 1364.

Candela, Y. 2010. Phylogenetic relationships of leptellinid brachiopods. Alcheringa 35:413-426.

Carlini, A. A., M. R. Ciancio, J. J. Flynn, G. J. Scillato-Yané, and A. R. Wyss. 2009. The phylogenetic and biostratigraphic significance of new armadillos (Mammalia, Xenarthra, Dasypodidae, Euphractinae) from the Tinguirirican (Early Oligocene) of Chile. Journal of Systematic Palaeontology 7:489-503.

Carlson, S. J., and P. C. Fitzgerald. 2007. Sampling taxa, estimating phylogeny and inferring macroevolution: an example from Devonian terebratulide brachiopods. Earth and Environmental Science Transactions of the Royal Society of Edinburgh 98:311-325.

Carr, R. K., and W. J. Hlavin. 2010. Two new species of Dunkleosteus Lehman, 1956, from the Ohio Shale Formation (USA, Famennian) and the Kettle Point Formation (Canada, Upper Devonian), and a cladistic analysis of the Eubrachythoraci (Placodermi, Arthrodira). Zoological Journal of the Linnean Society 159:195 - 222. 
Carrano, M. T., and S. D. Sampson. 2008. The phylogeny of Ceratosauria (Dinosauria). Journal of Systematic Palaeontology 6:183-236.

Cavin, L., V. Suteethorn, E. Buffetaut, and H. Tong. 2007. A new Thai Mesozoic lungfish (Sarcopterygii, Dipnoi) with an insight into post-Palaeozoic dipnoan evolution. Zoological Journal of the Linnean Society 149:141-177.

Chatterton, B. D. E., G. D. Edgecombe, B. G. Waisfeld, and N. E. Vaccari. 1998. Ontogeny and systematics of Toernquiestiidae (Trilobita, Proetida) from the Ordovician of the Argentine Precordillera. Journal of Paleontology 72:273 303.

Christiansen, P., and N. Bonde. 2002. A new species of gigantic mosasaur from the Late Cretaceous of Israel. Journal of Vertebrate Paleontology 22:629 - 644.

Ciampaglio, C. N. 2002. Determining the role that ecological and developmental constraints play in controlling disparity: examples from the crinoid and blastozoan fossil record. Evolution and Development 4:170 - 188.

Cisneros, J. C. 2008. Phylogenetic relationships of procolophonid parareptiles with remarks on their geological record. Journal of Systematic Palaeontology 6:345-366

Clement, G. 2005. A new coelacanth (Actinistia, Sarcopterygii) from the Jurassic of France, and the question of the closest fossil relative to Latimeria. Journal of Vertebrate Paleontology 25:481 - 491.

Cloutier, R. 1991. Patterns, trends and rates of evolution within the Actinistia. Environmental Biology of Fishes 32:23 - 58.

Cloutier, R., and P. E. Ahlberg. 1995. Morphology, characters, and the interrelationships of basal sarcopterygians. Pp. 445 - 479 in M. L. J. Siassny and L. Parenti, eds. Interrelationships of fishes, II. Academic Press, London.

Congreve, C. R., and B. S. Lieberman. 2010. Phylogenetic and biogeographic analysis of deiphonine trilobites. Journal of Paleontology 84:128 - 136.

\section{sphaerexochine trilobites. PLoS ONE 6:e21304.}

Cotton, T. J. 2001. The phylogeny and systematics of blind Cambrian ptychoparioid trilobites. Palaeontology 44:167 - 207.

Cotton, T. J., and S. J. Braddy. 2003. The phylogeny of arachnomorph arthropods and the origin of the Chelicerata. Earth and Environmental Science Transactions of the Royal Society of Edinburgh 94:169-193.

Cotton, T. J., and R. A. Fortey. 2005. Comparative morphology and relationships of the Agnostida. Pp. 95-136 in S. Koenemann and R. A. Jenner, eds. Crustacea and arthropod relationships. Taylor \& Francis, Boca Raton. Cripps, A. P. 1991. A cladistic analysis of the cornutes (stem chordates). Zoological Journal of the Linnean Society 102:333 - 366. 
Crônier, C. 2003. Systematic relationships of the blind phacopine trilobite Trimerocephalus, with a new species from Causses-et-Veyran, Montagne Noire. Acta Palaeontologica Polonica 48:55 - 70.

Cusack, M., A. Williams, and J. O. Buckman. 1999. Chemico-structural evolution of linguloid brachiopod shells. Palaeontology 42:799 - 840 .

D'Emic, M. D. 2012. The early evolution of titanosauriform sauropod dinosaurs. Zoological Journal of the Linnean Society 166:624-671.

Daley, P. E. J. 1992. The anatomy of the solute Girvanicystis batheri (?Chordata) from the Upper Ordovician of Scotland and a new species of Girvanicystis from the Upper Ordovician of South Wales. Zoological Journal of the Linnean Society 105:353 - 375.

Damiani, R. J. 2001. A systematic revision and phylogenetic analysis of Triassic mastodonsauroids (Temnospondyli: Stereospondyli). Zoological Journal of the Linnean Society 133:379 - 482.

Damiani, R. J., C. Vasconcelos, A. Renaut, J. Hancox, and A. Yates. 2007. Dolichuranus primaevus (Therapsida: Anomodontia) from the Middle Triassic of Namibia and its phylogenetic relationships. Palaeontology 50:1531 - 1546.

Dashzeveg, D., and J. Meng. 1998. New Eocene ctenodactyloid rodents from the Eastern Gobi Desert of Mongolia and a phylogenetic analysis of ctenodactyloids based on dental features. American Museum Novitates 3246:1 -20 .

Davidson, E. H., and D. H. Erwin. 2006. Gene Regulatory Networks and the evolution of animal body plans. Science 311:796-800.

Davidson, E. H., and D. H. Erwin. 2010. Evolutionary innovation and stability in animal gene networks. Journal of Experimental Zoology Part B: Molecular and Developmental Evolution 314B:182-186.

de Maintenon, M. J. 2005. Phylogenetic relationships of the tropical American columbellid taxa Conella, Eurypyrene, and Parametaria (Gastropoda: Neogastropoda). Journal of Paleontology 79:497 - 508.

Dean Shackleton, J. 2005. Skeletal homologies, phylogeny and classification of the earliest asterozoan echinoderms. Journal of Systematic Palaeontology 3:29-114.

Dewing, K. 2004. Shell structure and its bearing on the phylogeny of Late Ordovician-Early Silurian strophomenoid brachiopods from Anticosti Island, Quebec. Journal of Paleontology 78:275 - 286.

Dietze, K. 2000. A revision of paramblypterid and amblypterid actinopterygians from Upper Carboniferous - Lower Permian lacustrine deposites of Central Europe. Palaeontology 43:927 - 966.

Dilkes, D. W. 1998. The early Triassic rhynchosaur Mesosuchus browni and the interrelationships of basal archosauromorph reptiles. Philosophical 
Transactions of the Royal Society of London Series B: Biological Sciences 353:501 - 541.

Donoghue, P. C. J. 2001. Conodonts meet cladistics: recovering relationships and assessing the completeness of the fossil record. Palaeontology 44:65 - 93.

Dortangs, R. W., A. S. Schulp, E. W. A. Mulder, J. W. M. Jagt, H. H. G. Peeters, and D. T. d. Graaf. 2002. A large new mosasaur from the Upper Cretaceous of the Netherlands. Netherlands Journal of Geosciences 81:1 - 8 .

Dupret, V. 2004. The phylogenetic relationships between actinolepids (Placodermi: Arthrodira) and other arthrodires (phlyctaeniids and brachythoracids). Fossils and Strata 50:44 - 55.

Dupret, V., and M. Zhu. 2007. The earliest phyllolepid (Placodermi, Arthrodira) from the Late Lochkovian (Early Devonian) of Yunnan (South China). Geological Magazine 145:257 - 278.

Ebach, M. C. 2002. Lower Devonian trilobites from Cobar, New South Wales. Records of the Western Australian Museum 20:353 - 378.

Ebach, M. C., and S. T. Ahyong. 2001. Phylogeny of the trilobite subgenus Acanthopyge (Lobopyge). Cladistics 17:1 - 10.

Ebbestad, J. O. R., and G. E. Budd. 2002. Burlingiid trilobites from Norway, with a discussion of their affinities and relationships. Palaeontology 45:1171 - 1195 .

Eble, G. J. 2004. The macroevolution of phenotypic integration. Pp. 253 - 273 in M. Pigliucci and K. Preston, eds. Phenotypic integration: studying the ecology and evolution of complex phenotypes. Oxford University Press, Oxford.

Edgecombe, G., and L. Ramsköld. 1994. Earliest Devonian phacopide trilobites from central Bolivia. Paläontologische Zeitschrift 68:397-410.

Erwin, D. H. 2007. Disparity: morphological pattern and developmental context. Palaeontology 50:57-73.

Experimental Zoology Part B: Molecular and Developmental Evolution 318:460 - 465.

Estabrook, G. F., C. S. Johnson, Jr., and F. R. McMorris. 1975. An idealized concept of the true cladistic character. Mathematical Biosciences 23:263 - 272.

Estabrook, G. F., and F. R. McMorris. 2006. The compatibility of stratigraphic and comparative constraints on estimates of ancestor-descendant relations. Systematics and Biodiversity 4:9 - 17.

Finarelli, J. A., and W. C. Clyde. 2004. Reassessing hominoid phylogeny: evaluating congruence in the morphological and temporal data. Paleobiology 30:614 - 651.

Foote, M. 1991. Morphological and taxonomic diversity in a clade's history: the blastoid record and stochastic simulations. Contributions from the Museum of Paleontology, the University of Michigan 28:101 - 140. 
1992. Paleozoic record of morphological diversity in

blastozoan echinoderms. Proceedings of the National Academy of Sciences, USA 89:7325 - 7329.

. 1993a. Discordance and concordance between

morphological and taxonomic diversity. Paleobiology 19:185 - 204.

1993b. Contributions of individual taxa to overall

morphological disparity. Paleobiology 19:403 - 419.

. 1994. Morphological disparity in Ordovician - Devonian

crinoids and the early saturation of morphological space. Paleobiology 20:320 -344 .

in D. Jablonski, D. H. Erwin and J. H. Lipps, eds. Evolutionary paleobiology: essays in honor of James W. Valentine. University of Chicago Press, Chicago.

Post-Paleozoic crinoids. Science 274:1492 - 1495.

Foote, M., J. P. Hunter, C. M. Janis, and J. J. Sepkoski, Jr. 1999. Evolutionary and preservational constraints on origins of biologic groups: divergence times of eutherian mammals. Science 283:1310 - 1314.

Forey, P. L. 1991. Latimeria chalumnae and its pedigree. Environmental Biology of Fishes 32:75 - 97.

Friedman, M. 2007. The interrelationships of Devonian lungfishes (Sarcopterygii: Dipnoi) as inferred from neurocranial evidence and new data from the genus Soederberghia Lehman, 1959. Zoological Journal of the Linnean Society 151:115-171.

Fröbisch, J. 2007. The cranial anatomy of Kombuisia frerensis Hotton (Synapsida, Dicynodontia) and a new phylogeny of anomodont therapsids. Zoological Journal of the Linnean Society 150:117-144.

Froehlich, D. J. 2002. Quo vadis Eohippus? The systematics and taxonomy of the early Eocene equids (Perissodactyla). Zoological Journal of the Linnean Society 134:141 - 256.

Gahn, F. J., and T. W. Kammer. 2002. The cladid crinoid Barycrinus from the Burlington Limestone (Early Osagean) and the phylogenetics of Mississippian botyrocrinids. Journal of Paleontology 76:123 - 133.

Gasparini, Z., D. Pol, and L. A. Spalletti. 2006. An unusual marine crocodyliform from the Jurassic-Cretaceous boundary of Patagonia. Science 311:70-73.

Gelfo, J. N., G. M. Lopez, and M. Bond. 2008. A new Xenungulata (Mammalia) from the Paleocene of Patagonia, Argentina. Journal of Paleontology 82:329 335. 
Geraads, D., C. Blondel, A. Likius, H. T. Mackaye, P. Vignaud, and M. Brunet. 2008. New Hippotragini (Bovidae, Mammalia) from the Late Miocene of Toros-Menalla (Chad). Journal of Vertebrate Paleontology 28:231-242.

Gerber, S. 2013. On the relationship between the macroevolutionary trajectories of morphological integration and morphological disparity. PLoS One 8:e63913.

Gerber, S., G. J. Eble, and P. Neige. 2011. Developmental aspects of morphological disparity dynamics: a simple analytical exploration. Paleobiology 37:237-251.

Goin, F. J., A. M. Candela, M. A. Abello, and E. V. Oliveira. 2009. Earliest South American paucituberculatans and their significance in the understanding of 'pseudodiprotodont' marsupial radiations. Zoological Journal of the Linnean Society 155:867-884.

Goswami, A. 2006. Cranial modularity shifts during mammalian evolution. The American Naturalist 168:270-280.

Goswami, A., and P. D. Polly. 2010. The influence of modularity on cranial morphological disparity in Carnivora and Primates (Mammalia). PLoS One 5:e9517.

Grande, L., and W. E. Bemis. 1998. A comprehensive phylogenetic study of Amiid fishes (Amiidae) based on comparative skeletal anatomy. An empirical search for interconnected patterns of natural history. Memoirs of the Society of Vertebrate Paleontology 4:1 - 690.

Grégoire, M., J. Guo, and K. C. Beard. 2004. A new small dichobunid artiodactyl from Shanghuang (Middle Eocene, eastern China): implications for the early evolution of proto-selenodonts in Asia. Bulletin of Carnegie Museum of Natural History 36:177-197.

Haasl, D. M. 2000. Phylogenetic relationships among nassariid gastropods. Journal of Paleontology 74:839 - 852.

Hanger, R. A., and E. E. Strong. 2000. Phylogeny of the Anopliidae (Brachiopoda: Chonetidina). Historical Biology 14:285 - 298.

Harmon, L. J., J. B. Losos, T. Jonathan Davies, R. G. Gillespie, J. L. Gittleman, W. Bryan Jennings, K. H. Kozak, M. A. McPeek, F. Moreno-Roark, T. J. Near, A. Purvis, R. E. Ricklefs, D. Schluter, J. A. Schulte Ii, O. Seehausen, B. L. Sidlauskas, O. Torres-Carvajal, J. T. Weir, and A. Ø. Mooers. 2010. Early bursts of body size and shape evolution are rare in comparative data. Evolution 64:2385-2396.

Harris, J. D. 2006. The significance of Suuwassea emilieae (Dinosauria: Sauropoda) for flagellicaudatan intrarelationships and evolution. Journal of Systematic Palaeontology 4:185 - 198. 
Harrison, L., and H. C. E. Larsson. 2015. Among-character rate variation distributions in phylogenetic analysis of discrete morphological characters. Systematic Biology 64:307 - 324.

Harvey, E. W., and W. I. Ausich. 1997. Phylogeny of calceocrinid crinoids (Paleozoic: Echinodermata): biogeography and mosaic evolution. Journal of Paleontology 71:299 - 305.

Holbrook, L. T. 2001. Comparative osteology of early Tertiary tapiromorphs (Mammalia, Perissodactyla). Zoological Journal of the Linnean Society 132:1 $-54$.

Hooker, J. J., and D. Dashzeveg. 2004. The origin of chalicotheres (Perissodactyla, Mammalia). Palaeontology 47:1363 - 1386.

Hooker, J. J., and D. E. Russell. 2012. Early Palaeogene Louisinidae (Macroscelidea, Mammalia), their relationships and north European diversity. Zoological Journal of the Linnean Society 164:856-936.

Hopkins, M. J. 2011. Species-level phylogenetic analysis of pterocephaliids (Trilobita, Cambrian) from the Great Basin, Western USA. Journal of Paleontology 85:1128-1153.

Hopkins, M. J., and A. B. Smith. 2015. Dynamic evolutionary change in postPaleozoic echinoids and the importance of scale when interpreting changes in rates of evolution. Proceedings of the National Academy of Sciences 112:3758-3763.

Hopkins, S. S. B. 2008. Phylogeny and evolutionary history of the Aplodontoidea (Mammalia: Rodentia). Zoological Journal of the Linnean Society 153:769838.

Hoyal Cuthill, J. 2015. The size of the character state space affects the occurrence and detection of homoplasy: Modelling the probability of incompatibility for unordered phylogenetic characters. Journal of Theoretical Biology 366:24-32.

Huelsenbeck, J. P. 1994. Comparing the stratigraphic record to estimates of phylogeny. Paleobiology 20:470 - 483.

Hughes, M., S. Gerber, and M. A. Wills. 2013. Clades reach highest morphological disparity early in their evolution. Proceedings of the National Academy of Sciences 110:13875-13879.

Hughes, N. C., and A. W. A. Rushton. 1990. Computer-aided restoration of a Late Cambrian ceratopygid trilobite from Wales, and its phylogenetic implications. Palaeontology 33:429-445.

Huttenlocker, A. 2009. An investigation into the cladistic relationships and monophyly of therocephalian therapsids (Amniota: Synapsida). Zoological Journal of the Linnean Society 157:865-891.

Huttenlocker, A. K., C. A. Sidor, and R. M. H. Smith. 2011. A new specimen of Promoschorhynchus (Therapsida: Therocephalia: Akidnognathidae) from the 
Lower Triassic of South Africa and its implications for theriodont survivorship across the Permo-Triassic boundary. Journal of Vertebrate Paleontology 31:405-421.

Hwang, S. H., M. A. Norell, J. I. Qiang, and G. A. O. Keqin. 2002. New specimens of Microraptor zhaoianus (Theropoda: Dromaeosauridae) from northeastern China. American Museum Novitates 381:1 - 44.

Jeffery, C. H. 1999. A reappraisal of the phylogenetic relationships of somaliasterid echinoids. Palaeontology 42:1027 - 1042.

Jeffery, C. H., and R. B. Emlet. 2003. Macroevolutionary consequences of developmental mode in temnopleurid echinoids from the Tertiary of Southern Australia. Evolution 57:1031-1048.

Jiang, H., R. J. Aldridge, X. Lai, C. Yan, and Y. Sun. 2011. Phylogeny of the conodont genera Hindeodus and Isarcicella across the Permian-Triassic boundary. Lethaia 44:374 - 382.

Jin, J., and L. E. Popov. 2008. A new genus of Late Ordovician-Early Silurian pentameride brachiopods and its phylogenetic relationships. Acta Palaeontologica Polonica 53:221-236.

Johanson, Z., J. A. Long, J. A. Talent, P. Janvier, and J. W. Warren. 2006. Oldest coelacanth, from the Early Devonian of Australia. Biology Letters 2:443-446.

Johnson, H. G., D. K. Elliott, and J. H. Wittke. 2000. A new actinolepid arthrodire (Class Placodermi) from the Lower Devonian Sevy Dolomite, eastcentral Nevada. Zoological Journal of the Linnean Society 129:241 - 266.

Joyce, W. G. 2007. Phylogenetic relationships of Mesozoic turtles. Bulletin of the Peabody Museum of Natural History 48:3-102.

Kammer, T. W., and F. J. Gahn. 2003. Primitive cladid crinoids from the early Osagean Burlington Limestone and the phylogenetics of Mississippian species of Cyathocrinites. Journal of Paleontology 77:121 - 138.

Kammerer, C. F., J. J. Flynn, L. Ranivoharimanana, and R. R. Wyss. 2008. New material of Menadon besairiei (Cynodontia: Traversodontidae) from the Triassic of Madagascar. Journal of Vertebrate Paleontology 28:445-462.

Karasawa, H., and C. E. Schweitzer. 2006. A new classification of the Xanthoidea sensu lato (Crustacea: Decapoda: Brachyura) based on phylogenetic analysis and traditional systematics and evaluation of all fossil Xanthoidea sensu lato. Contributions to Zoology 75:23 - 73.

Kellner, A. W. A., A. E. P. Pinheiro, and D. A. Campos. 2014. A new sebecid from the Paleogene of Brazil and the crocodyliform radiation after the $\mathrm{K}-\mathrm{Pg}$ Boundary. PLoS ONE 9:e81386.

Kielan-Jaworowska, Z., and J. H. Hurum. 2001. Phylogeny and systematics of multituberculate mammals. Palaeontology 44:389-429. 
Kohno, N. 2006. A new Miocene odobenid (Mammalia: Carnivora) from Hokkaido, Japan, and its implications for odobenid phylogeny. Journal of Vertebrate Paleontology 26:411-421.

Korn, D. 1997. Evolution of the Goniatitaceae and Viséan-Namurian biogeography. Acta Palaeontologica Polonica 42:177 - 199.

Kroh, A. 2007. Hemipatagus, a misinterpreted loveniid (Echinodermata: Echinoidea). Journal of Systematic Palaeontology 5:163 - 192.

Lamsdell, J. C., S. J. Braddy, and O. E. Tetlie. 2010. The systematics and phylogeny of the Stylonurina (Arthropoda: Chelicerata: Eurypterida). Journal of Systematic Palaeontology 8:49 - 61.

Laurin, M., and R. Soler-Gijón. 2006. The oldest known stegocephalian (Sarcopterygii: Temnospondyli) from Spain. Journal of Vertebrate Paleontology 26:284 - 299.

Le Quesne, W. J. 1969. A method of selection of characters in numerical taxonomy. Systematic Zoology 18:201 - 205.

Lee, S.-b., D.-C. Lee, and D. K. Choi. 2008. Cambrian-Ordovician trilobite family Missisquoiidae Hupè, 1955: systematic revision and palaeogeographical considerations based on cladistic analysis. Palaeogeography, Palaeoclimatology, Palaeoecology 260:315-341.

Lefebvre, B. 2001. A critical comment on 'ankyroids' (Echinodermata, Stylophora). Geobios 34:597 - 627.

Leighton, L. R., and C. G. Maples. 2002. Evaluating internal versus external characters: phylogenetic analyses of the Echinoconchidae, Buxtoniinae, and Juresaniinae (Phylum: Brachiopoda). Journal of Paleontology 76:659 - 671.

Lieberman, B. S. 1993. Systematics and biogeography of the "Metacryphaeus group" Calmoniidae (Trilobita, Devonian), with comments on adaptive radiations and the geological history of the Malvinokaffric Realm. Journal of Paleontology 67:549 - 570.

1864 , and the origin, diversification, evolutionary affinity, and extinction of the Middle Devonian proetid fauna of eastern North America. Bulletin of the American Museum of Natural History 223:1 - 176.

1999. Testing the Darwinian legacy of the Cambrian radiation using trilobite phylogeny and biogeography. Journal of Paleontology $73: 176-181$. (Trilobita, Cambrian). Journal of Paleontology 75:96 - 115. trilobites, the biogeographic origins of the Eutrilobita, and the timing of the Cambrian radiation. Journal of Paleontology 76:692-708. 
Lieberman, B. S., G. D. Edgecombe, and N. Eldredge. 1991. Systematics and biogeography of the "Malvinella group," Calmoniidae (Trilobita, Devonian). Journal of Paleontology 65:824 - 843.

Lieberman, B. S., and G. J. Kloc. 1997. Evolutionary and biogeographic patterns in the Asteropyginae (Trilobita, Devonian) Delo, 1935. Bulletin of the American Museum of Natural History 232:1 - 127.

López-Antoñanzas, R., and S. Sen. 2006. New Saudi Arabian Miocene jumping mouse (Zapodidae): systematics and phylogeny. Journal of Vertebrate Paleontology 26:170-181.

López-Arbarello, A. 2012. Phylogenetic interrelationships of ginglymodian fishes (Actinopterygii: Neopterygii). PLoS ONE 7:e39370.

López-Arbarello, A., and A. M. Zavattieri. 2008. Systematic revision of Pseudobeaconia Bordas, 1944, and Mendocinichthys Whitley, 1953 (Actinopterygii: 'Perleidiformes') from the Triassic of Argentina. Palaeontology 51:1025 - 1052.

Lü, J., D. M. Unwin, X. Jin, Y. Liu, and Q. Ji. 2010. Evidence for modular evolution in a long-tailed pterosaur with a pterodactyloid skull. Proceedings of the Royal Society B: Biological Sciences 277:383 - 389.

Lupia, R. 1999. Discordant morphological disparity and taxonomic diversity during the Cretaceous angiosperm radiation: North American pollen record. Paleobiology 25:1 - 28.

Lyson, T. R., and W. G. Joyce. 2009. A new species of Palatobaena (Testudines: Baenidae) and a Maximum Parsimony and Bayesian phylogenetic analysis of Baenidae. Journal of Paleontology 83:457 - 470.

Makovicky, P. J., and M. A. Norell. 2006. Yamaceratops dorngobiensis, a new primitive ceratopsian (Dinosauria: Ornithischia) from the Cretaceous of Mongolia. American Museum Novitates 3530:1 - 42.

Makovicky, P. J., and H.-D. Sues. 1998. Anatomy and phylogenetic relationships of the theropod dinosaur Microvenator celer from the Lower Cretaceous of Montana. American Museum Novitates 3240:1 - 27.

Marivaux, L., M. Adaci, M. Bensalah, H. G. Rodrigues, L. Hautier, M. h. Mahboubi, F. Mebrouk, R. Tabuce, and M. Vianey-Liaud. 2011. Zegdoumyidae (Rodentia, Mammalia), stem anomaluroid rodents from the Early to Middle Eocene of Algeria (Gour Lazib, Western Sahara): new dental evidence. Journal of Systematic Palaeontology 9:563-588.

Marshall, C. R. 2014. The evolution of morphogenetic fitness landscapes: conceptualising the interplay between the developmental and ecological drivers of morphological innovation. Australian Journal of Zoology 62:3-17.

McDonald, A. T. 2012. Phylogeny of basal iguanodonts (Dinosauria: Ornithischia): an update. PLoS ONE 7:e36745. 
McGowan, A. J., and A. B. Smith. 2007. Ammonoids across the Permian/Triassic boundary: a cladistic perspective. Palaeontology 50:573-590.

Meacham, C. A. 1984. The role of hypothesized direction of characters in the estimation of evolutionary history. Taxon 33:26-38.

Merle, D., and J.-M. Pacaud. 2003. New species of Eocithara Fischer, 1883 (Mollusca, Gastropoda, Harpidae) from the Early Paleogene with phylogenetic analysis of the Harpidae. Geodiversitas 26:61 - 87.

Métais, G. 2006. New basal selenodont artiodactyls from the Pondaung Formation (Late Middle Eocene, Myanmar and the phylogenetic relationships of early ruminants. Annals of Carnegie Museum 75:51 - 67.

Métais, G., J. Guo, and K. C. Beard. 2004. A new small dichobunid artiodactyl from Shanghuang (Middle Eocene, Eastern China): Implications for the early evolution of proto-selenodonts in Asia. Bulletin of Carnegie Museum of Natural History 36:177-197.

Michaux, B. 1989. Cladograms can reconstruct phylogenies: an example from the fossil record. Alcheringa 13:21 - 36.

Mihlbachler, M. C. 2008. Species taxonomy, phylogeny, and biogeography of the Brontotheriidae (Mammalia: Perissodactyla). Bulletin of the American Museum of Natural History 311:1 - 475.

Mitchell, S. F. 2013. Revision of the Antillocaprinidae Mac Gillavry (Hippuritida, Bivalvia) and their position within the Caprinoidea d'Orbigny. Geobios 46:423-446.

Monari, S. 2009. Phylogeny and biogeography of pholadid Bivalve Barnea (Anchomasa) with considerations on the phylogeny of Pholadoidea. Acta Palaeontologica Polonica 54:315-335.

Monks, N. 1999. Cladistic analysis of Albian heteromorph ammonites. Palaeontology 42:907 - 925.

. 2000. Functional morphology, ecology, and evolution of the Scaphitaceae Gill, 1871 (Cephalopoda). Journal of Molluscan Studies 66:205216.

2002. Cladistic analysis of a problematic ammonite group: the Hamitidae (Cretaceous, Albian-Turonian) and proposals for new cladistic terms. Palaeontology 45:689 - 707.

Motani, R. 1999. Phylogeny of the Ichthyopterygia. Journal of Vertebrate Paleontology 19:473 - 496.

Nardin, E., and J. Bohatý. 2013. A new pleurocystitid blastozoan from the Middle Devonian of the Eifel (Germany) and its phylogenetic importance. Acta Palaeontologica Polonica 58:533-544. 
Nasif, N. L., S. Musalem, and E. Cerdeño. 2000. A new toxodont from the Late Miocene of Catamarca, Argentina, and a phylogenetic analysis of the Toxodontidae. Journal of Vertebrate Paleontology 20:591-600.

Ni, X., J. Meng, K. C. Beard, D. L. Gebo, Y. Wang, and C. Li. 2010. A new tarkadectine primate from the Eocene of Inner Mongolia, China: phylogenetic and biogeographic implications. Proceedings of the Royal Society B: Biological Sciences 277:247-256.

Nützel, A., D. H. Erwin, and R. H. Mapes. 2000. Identity and phylogeny of the Late Paleozoic Subulitoidea (Gastropoda). Journal of Paleontology 74:575 598.

O'Keefe, F. R. 2001. A cladistic analysis and taxonomic revision of the Plesiosauria (Reptilia: Sauropterygia). Acta Zoologica Fennica 213:1 - 63. O'Keefe, F. R., and P. J. Wagner. 2001. Inferring and testing hypotheses of correlated character evolution by using character compatibility. Systematic Biology 50:657 - 675 .

Ösi, A. 2005. Hungarosaurus tormai, a new ankylosaur (Dinosauria) from the Upper Cretaceous of Hungary. Journal of Vertebrate Paleontology 25:370-383.

Parsley, R. L. 1997. The echinoderm classes Stylophora and Homoiostelea: non Calcichordata. Pp. 225 - 248 in J. A. Waters and C. G. Maples, eds. Geobiology of echinoderms. The Paleontological Society, Knoxville.

Parsley, R. L., and C. D. Sumrall. 2007. New recumbent echinoderm genera from the Bois d'Arc Formation: Lower Devonian (Lochkovian) of Coal County, Oklahoma. Journal of Paleontology 81:1486-1493.

Paterson, J. R., and G. D. Edgecombe. 2006. The Early Cambrian trilobite family Emuellidae Pocock, 1970: systematic position and revision of Australian species. Journal of Paleontology 80:496-513.

Patterson, C. 1982. Morphological characters and homology. Pp. 21 - 74 in K. A. Joysey and A. E. Friday, eds. Problems of phylogenetic reconstruction. Academic Press, London.

Pernègre, V. N., and D. K. Elliott. 2008. Phylogeny of the Pteraspidiformes (Heterostraci), Silurian-Devonian jawless vertebrates. Zoologica Scripta 37:391-403.

Piras, P., and A. D. Buscalioni. 2006. Diplocynodon muelleri comb. nov., an Oligocene diplocynodontine alligatoroid from Catalonia (Ebro Basin, Lleida Province, Spain). Journal of Vertebrate Paleontology 26:608-620.

Pol, D., J. M. Leardi, A. Lecuona, and M. Krause. 2012. Postcranial anatomy of Sebecus icaeorhinus (Crocodyliformes, Sebecidae) from the Eocene of Patagonia. Journal of Vertebrate Paleontology 32:328-354.

Pollitt, J. R., R. A. Fortey, and M. A. Wills. 2005. Systematics of the trilobite families Lichidae Hawle \& Corda, 1847 and Lichakephalidae Tripp, 1957: the 
application of Bayesian inference to morphological data. Journal of Systematic Palaeontology 3:225 - 241.

Polly, P. D. 1996. The skeleton of Gazinocyon vulpeculus gen. et. comb nov. and the cladistic relationships of Hyaenodontidae (Eutheria, Mammalia). Journal of Vertebrate Paleontology 16:303 - 319.

Polly, P. D. 1998. Variability, selection, and constraints: development and evolution in viverravid (Carnivora, Mammalia) molar morphology. Paleobiology 24:409 - 429.

Popov, L. E., I. F. Nikitin, and E. V. Sokiran. 1999. The earliest atrypides and athyridides (Brachiopoda) from the Ordovician of Kazakhstan. Palaeontology 42:625-661.

Popov, L. E., O. Vinn, and O. I. Nikitina. 2001. Brachiopods of the redefined family Tritoechiidae from the Ordovician of Kazakhstan and South Urals. Geobios 34:131-155.

Prado, J. L., and M. T. Alberdi. 1996. A cladistic analysis of the horses of the tribe Equini. Palaeontology 39:663 - 680.

Prieto-Márquez, A. 2010. Global phylogeny of Hadrosauridae (Dinosauria: Ornithopoda) using parsimony and Bayesian methods. Zoological Journal of the Linnean Society 159:435-502.

Pujos, F., G. De Iuliis, C. Argot, and L. Werdelin. 2007. A peculiar climbing Megalonychidae from the Pleistocene of Peru and its implication for sloth history. Zoological Journal of the Linnean Society 149:179-235.

Rabosky, D. L., F. Santini, J. Eastman, S. A. Smith, B. Sidlauskas, J. Chang, and M. E. Alfaro. 2013. Rates of speciation and morphological evolution are correlated across the largest vertebrate radiation. Nature Communications 4:nc2958.

Ramsköld, L., and B. D. E. Chatterton. 1991. Revision and subdivision of the polyphyletic 'Leonaspis' (Trilobita). Transactions of the Royal Society of Edinburgh: Earth Sciences 82:333 - 371.

Ramsköld, L., and L. Werdelin. 1991. The phylogeny and evolution of some phacopid trilobites. Cladistics 7:29 - 74.

Raup, D. M., and S. J. Gould. 1974. Stochastic simulation and evolution of morphology - towards a nomothetic paleontology. Systematic Zoology 23:305 $-322$.

Reynoso, V.-H. 1996. A Middle Jurassic Sphenodon-like sphenodontian (Diapsida: Lepidosauria) from Huizachal Canyon, Tamaulipas, Mexico. Journal of Vertebrate Paleontology 16:210-221.

Rode, A. L. 2004. Phylogenetic revision of Leptodesma (Leiopteria) (Devonian: Bivalvia). Postilla 229:1 - 26. 
Rode, A. L., and L. E. Babcock. 2003. Phylogeny of fossil and extant freshwater crayfish and some closely related nephropid lobsters. Journal of Crustacean Biology 23:418 - 435.

Rode, A. L., and B. S. Lieberman. 2002. Phylogenetic and biogeographic analysis of Devonian phyllocarid crustaceans. Journal of Paleontology 76:271 - 286.

Roopnarine, P. D. 2001. A history of diversification, extinction, and invasion in tropical America as derived from species-level phylogenies of chionine genera (Family Veneridae). Journal of Paleontology 75:644 - 657.

Rougier, G. W., S. Isaji, and M. Manabe. 2007. An Early Cretaceous mammal from the Kuwajima Formation (Tetori Group), Japan, and a reassessment of triconodont phylogeny. Annals of the Carnegie Museum 76:73-115.

Rougier, G. W., M. J. Novacek, M. C. McKenna, and J. R. Wible. 2001. Gobiconodonts from the Early Cretaceous of Oshih (Ashile), Mongolia. American Museum Novitates 3348:1-30.

Rulleau, L., M. Bécaud, and P. Neige. 2003. Ammonites generally classified in the Bouleiceratinae sub-family (Hildoceratidae, Toarcian): phylogenetic, biogeographic and systematic perspective. Geobios 36:317 - 348.

Ruta, M. 1997. A new mitrate from the Lower Ordovician of Southern France. Palaeontology 40:363 - 383.

1999. A cladistic analysis of the anomalocystitid mitrates. Zoological Journal of the Linnean Society 127:345 - 421.

Ruta, M., and J. N. Theron. 1997. Two Devonian mitrates from South Africa. Palaeontology 40:201 - 243.

Salisbury, B. A. 1999. Strongest evidence in compatibility: clique and tree evaluation using apparent phylogenetic signal. Taxon 48:755-766.

Salisbury, S. W., R. E. Molnar, E. Frey, and P. M. Willis. 2006. The origin of modern crocodyliforms: new evidence from the Cretaceous of Australia.

Proceedings of the Royal Society B: Biological Sciences 273:2439 - 2448.

Sampson, S. D., M. A. Loewen, A. A. Farke, E. M. Roberts, C. A. Forster, J. A. Smith, and A. L. Titus. 2010. New horned dinosaurs from Utah provide evidence for intracontinental dinosaur endemism. PLoS Biol 5:1 - 12.

Sansom, R. S. 2008. The origin and early evolution of the Osteostraci (Vertebrata): a phylogeny for the Thyestiida. Journal of Systematic Palaeontology 6:317 - 332.

Santini, F., and J. C. Tyler. 2003. A phylogeny of the families of fossil and extant tetraodontiform fishes (Acanthomorpha, Tetraodontiformes), Upper Cretaceous to Recent. Zoological Journal of the Linnean Society 139:565 617. 
Saucède, T., R. Mooi, and B. David. 2007. Phylogeny and origin of Jurassic irregular echinoids (Echinodermata: Echinoidea). Geological Magazine $144: 333$ - 359.

Saucède, T., and D. Neraudeau. 2006. An `Elvis' echinoid, Nucleopygus (Jolyclypus) jolyi, from the Cenomanian of France: phylogenetic analysis, sexual dimorphism and neotype designation. Cretaceous Research 27:542-554.

Schneider, J. A. 1998a. Phylogeny of stem-group eucardiids (Bivalvia: Cardiidae) and the significance of the transitional fossil Perucardia. Malacologia 40:37 62 . relationship and morphologic evolution within the subfamilies Clinocardiinae, Lymnocardiinae, Fraginae and Tridacninae. Malacologia 40:321 - 373.

Schoch, R. R. 2008a. A new stereospondyl from the German Middle Triassic, and the origin of the Metoposauridae. Zoological Journal of the Linnean Society $152: 79-113$.

and stratigraphy. Palaeodiversity 1:189-226.

Schoch, R. R., and A. R. Milner. 2008. The intrarelationships and evolutionary history of the temnospondyl family Branchiosauridae. Journal of Systematic Palaeontology 6:409 - 431.

Schram, F. R., C. H. J. Hof, and F. A. Steeman. 1999. Thylacocephala (Arthropoda: Crustacea?) from the Cretaceous of Lebanon and implications for Thylacocephalan systematics. Palaeontology 52:769 - 797.

Sepkoski, J. J., Jr. 1979. A kinetic model of Phanerozoic taxonomic diversity. II. Early Phanerozoic families and multiple equilibria. Paleobiology 5:222 - 251.

Shockey, B. J. 1997. Two new notoungulates (Family Notohippidae) from the Salla Beds of Bolivia (Deseadan: late Oligocene): systematics and functional morphology. Journal of Vertebrate Paleontology 17:584-599.

Shoshani, J., R. C. Walter, M. Abraha, S. Berhe, P. Tassy, W. J. Sanders, G. H. Marchant, Y. Libsekal, T. Ghirmai, and D. Zinner. 2006. A proboscidean from the Late Oligocene of Eritrea, a "missing link" between early Elephantiformes and Elephantimorpha, and biogeographic implications. Proceedings of the National Academy of Sciences 103:17296 - 17301.

Sidor, C. A., F. R. O'Keefe, R. Damiani, J. S. Steyer, R. M. H. Smith, H. C. E. Larsson, P. C. Sereno, O. Ide, and A. Maga. 2005. Permian tetrapods from the Sahara show climate-controlled endemism in Pangaea. Nature 434:886-889. Simóes, M. G., A. C. Marques, L. H. Cruz de Mello, and L. E. Anneli. 1997. Phylogenetic analysis of the genera of the extinct family Megadesmidae (Bivalvia, Anomalodesmata), with remarks on its paleoecology and taxonomy. Journal of Comparative Biology 2:75 - 90. 
Skelton, P. W., and A. B. Smith. 2000. A preliminary phylogeny for rudist bivalves: sifting clades from grades. Pp. 97 - 127 in E. M. Harper, J. D. Taylor and J. A. Crame, eds. The evolutionary biology of the Bivalvia. Special Publication of the Geological Society, London, Geological Society, London.

Slowinski, J. B., and C. Guyer. 1989. Testing null models in questions of evolutionary success. Systematic Zoology 38:189 - 191.

Smith, A. B. 1994. Triassic echinoids from Peru. Palaeontographica Abteilung A 233:177 - 202. echinoids using stratigraphically restricted parsimony analysis. Paleobiology $27: 392$ - 404 . and their migration into the Deep-sea. Palaeontology 47:123-150.

2004. Phylogeny and systematics of holasteroid echinoids 2007. Intrinsic versus extrinsic biases in the fossil record: contrasting the fossil record of echinoids in the Triassic and early Jurassic using sampling data, phylogenetic analysis, and molecular clocks. Paleobiology 33:310-323.

Smith, A. B., and C. W. Wright. 1993. British Cretaceous echinoids. Part 3, Stirodonta 2 (Hemicidaroida, Arbacioida and Phymosomatoida, Part 1). Monograph of the Palaeontolographical Society 147:199 - 267.

Smith, A. B., and S. Zamora. 2009. Rooting phylogenies of problematic fossil taxa; a case study using cinctans (stem-group echinoderms). Palaeontology 52:803-821.

Solé, F. 2013. New proviverrine genus from the Early Eocene of Europe and the first phylogeny of Late Palaeocene-Middle Eocene hyaenodontidans (Mammalia). Journal of Systematic Palaeontology 11:375 - 398.

Steyer, J. S., R. Damiani, C. A. Sidor, F. R. O'Keefe, H. C. E. Larsson, A. Maga, and O. Ide. 2006. The vertebrate fauna of the Upper Permian of Niger. IV. Nigerpeton ricqlesi (Temnospondyli: Cochleosauridae), and the edopoid colonization of Gondwana. Journal of Vertebrate Paleontology 26:18-28.

Stigall Rode, A. L. 2005. Systematic revision of the Middle and Late Devonian brachiopods Schizophoria (Schizophoria) and 'Schuchertella' from North America. Journal of Systematic Palaeontology 3:133 - 167.

Stocker, M. R. 2010. A new taxon of phytosaur (Archosauria: Pseudosuchia) from the Late Triassic (Norian) Sonsela Member (Chinle Formation) in Arizona, and a critical reevaluation of Leptosuchus Case, 1922. Palaeontology 53:997-1022.

2012. A new phytosaur (Archosauriformes, Phytosauria) from the Lot's Wife beds (Sonsela Member) within the Chinle Formation 
(Upper Triassic) of Petrified Forest National Park, Arizona. Journal of Vertebrate Paleontology 32:573-586.

Stockley, B., A. B. Smith, T. Littlewood, H. A. Lessios, and J. A. Mackenzie-

Dodds. 2005. Phylogenetic relationships of spatangoid sea urchins

(Echinoidea): taxon sampling density and congruence between morphological and molecular estimates. Zoologica Scripta 34:447-468.

Strait, D. S., and F. E. Grine. 2004. Inferring hominoid and early hominid phylogeny using craniodental characters: the role of fossil taxa. Journal of Human Evolution 47:399-452.

Sues, H.-D., and A. Averianov. 2009. A new basal hadrosauroid dinosaur from the Late Cretaceous of Uzbekistan and the early radiation of duck-billed dinosaurs. Proceedings of the Royal Society B: Biological Sciences 276:25492555.

Sumrall, C. D., and F. J. Gahn. 2006. Morphological and systematic reinterpretation of two enigmatic edrioasteroids (Echinodermata) from Canada. Canadian Journal of Earth Sciences 43:497 - 507.

Sumrall, C. D., and J. Sprinkle. 1995. Plating and pectinirhombs of the Ordovician rhombiferan Plethoschisma. Journal of Paleontology 69:772 - 779.

Sumrall, C. D., and S. Zamora. 2011. Ordovician edrioasteroids from Morocco: faunal exchanges across the Rheic Ocean. Journal of Systematic Palaeontology 9:425-454.

Sundberg, F. A. 1999. Redescription of Alokistocare subcoronatum (Hall and Whitfield, 1877), the type species of Alokistocare, and the status of Alokistocaridae Resser, 1939b (Ptychopariidae: Trilobita, Middle Cambrian. Journal of Paleontology 73:1126 - 1143.

. 2004. Cladistic analysis of Early-Middle Cambrian kochaspid trilobites (Ptychopariida). Journal of Paleontology 78:920 - 940. Sundberg, F. A. 2006. Taxonomic assignment of the Cambrian trilobite Tonkinella Mansuy, 1916 (Corynexochida), with a new species from California. Memoirs of the Association of Australasian Palaeontologists 32:59 $-74$.

Sundberg, F. A., and L. B. McCollum. 1997. Oryctocephalids (Corynexochida: Trilobita) of the Lower-Middle Cambrian boundary interval from California and Nevada. Journal of Paleontology 77:1065 - 1090.

Suter, S. J. 1994. Cladistic analysis of cassiduloid echinoids: trying to see the phylogeny for the trees. Biological Journal of the Linnean Society 53:31 - 72 .

Swartz, B. A. 2009. Devonian actinopterygian phylogeny and evolution based on a redescription of Stegotrachelus finlayi. Zoological Journal of the Linnean Society 156:750-784. 
Tetlie, O. E. 2006. Two new Silurian species of Eurypterus (Chelicerata: Eurypterida) from Norway and Canada and the phylogeny of the genus. Journal of Systematic Palaeontology 4:397 - 412.

Tetlie, O. E., and M. B. Cuggy. 2007. Phylogeny of the basal swimming eurypterids (Chelicerata; Eurypterida; Eurypterina). Journal of Systematic Palaeontology 5:345-356.

Thompson, R. S., J. C. Parish, S. C. R. Maidment, and P. M. Barrett. 2012. Phylogeny of the ankylosaurian dinosaurs (Ornithischia: Thyreophora). Journal of Systematic Palaeontology 10:301-312.

Thorne, P. M., M. Ruta, and M. J. Benton. 2011. Resetting the evolution of marine reptiles at the Triassic-Jurassic boundary. Proceedings of the National Academy of Sciences 108:8339-8344.

Tinn, O., and T. Meidla. 2004. Phylogenetic relationships of Early-Middle Ordovician ostracods of Baltoscandia. Palaeontology 47:199 - 221.

Tsuji, L. A., J. Müller, and R. R. Reisz. 2010. Microleter mckinzieorum gen. et sp. nov. from the Lower Permian of Oklahoma: the basalmost parareptile from Laurasia. Journal of Systematic Palaeontology 8:245-255.

Turvey, S. T. 2002. Phylogeny of the Reedocalymeninae (Trilobita): implications for Early Ordovician biogeography of Gondwana. Pp. 53 - 68 in J. A. Crame and A. W. Owen, eds. Palaeobiogeography and biodiversity change: the Ordovician and Mesozoic-Cenozoic radiations. Geological Society of London, Special Publications, London.

Uhen, M. D., and P. D. Gingerich. 2001. New genus of dorudontine archaeocete (Cetacea) from the middle-to-late Eocene of South Carolina. Marine Mammal Science 17:1-34.

Vermeij, G. J., and S. J. Carlson. 2000. The muricid gastropod subfamily Rapaninae: phylogeny and ecological history. Paleobiology 26:19 - 46. Villier, L., D. Blake, J. Jagt, and M. Kutscher. 2004. A preliminary phylogeny of the Pterasteridae (Echinodermata, Asteroidea) and the first fossil record: Late Cretaceous of Germany and Belgium. Paläontologische Zeitschrift 78:281-299. Wagner, G. P. 1989. The origin of morphological characters and the biological basis of homology. Evolution 43:1157 - 1171. modularity. American Zoologist 36:36-43.

Reviews Genetics 8:473-479.

Wagner, G. P., and L. Altenberg. 1996. Complex adaptations and the evolution of evolvability. Evolution 50:967 - 976.

Wagner, P. J. 1995a. Stratigraphic tests of cladistic hypotheses. Paleobiology $21: 153-178$. 
1995b. Testing evolutionary constraint hypotheses with early Paleozoic gastropods. Paleobiology 21:248 - 272.

Rostroconchia. Paleobiology 23:115 - 150.

- 1999a. The utility of fossil data in phylogenetic analyses: a likelihood example using Ordovician-Silurian species of the Lophospiridae (Gastropoda: Murchisoniina). American Malacological Bulletin 15:1 - 31. . 1999b. Phylogenetic relationships of the earliest anisostrophically coiled gastropods. Smithsonian Contributions to Paleobiology 88:1 - 132 .

phylogenetic inferences about sampling and diversity. Systematic Biology 49:65 - 86.

taxa. Evolution 54:365 - 386.

2000b. Exhaustion of cladistic character states among fossil . 2001. Gastropod phylogenetics: progress, problems and implications. Journal of Paleontology 75:1128 - 1140.

compatibility: implications for morphological evolution among fossil invertebrates. Biology Letters 8:143 - 146.

Wagner, P. J., and G. F. Estabrook. 2014. Trait-based diversification shifts reflect differential extinction among fossil taxa. Proceedings of the National Academy of Sciences 111:16419-16424.

. 2015. The implications of stratigraphic compatibility for character integration among fossil taxa. Systematic Biology 64:838 - 852.

Wagner, P. J., M. Ruta, and M. I. Coates. 2006. Evolutionary patterns in early tetrapods. II. Differing constraints on available character space among clades. Proceedings of the Royal Society of London, Series B. Biological Sciences 273:2113 - 2118.

Waisfeld, B. G., N. E. Vaccari, B. D. E. Chatterton, and G. D. Edgecombe. 2001. Systematics of Shumardiidae (Trilobita), with new species from the Ordovician of Argentina. Journal of Paleontology 75:827 - 859.

Wang, X., M. C. McKenna, and D. Dashzeveg. 2005. Amphicticeps and Amphicynodon (Arctoidea, Carnivora) from Hsanda Gol Formation, Central Mongolia and phylogeny of basal arctoids with comments on zoogeography. American Museum Novitates 3483:1 - 57.

Wang, X., R. H. Tedford, and B. E. Taylor. 1999. Phylogenetic systematics of the Borophaginae (Carnivora: Canidae). Bulletin of the American Museum of Natural History 243:1-392. 
Warren, A., and C. Marsicano. 2000. A phylogeny of the Brachyopoidea (Temnospondyli, Stereospondyli). Journal of Vertebrate Paleontology 20:462483.

Webster, M. 2007. A Cambrian peak in morphological variation within trilobite species. Science 317:499-502.

Webster, M., and M. L. Zelditch. 2011. Evolutionary lability of integration in Cambrian ptychoparioid trilobites. Evolutionary Biology 38:144-162.

Weishampel, D. B., C.-M. Jianu, Z. Csiki, and D. B. Norman. 2003. Osteology and phylogeny of Zalmoxes (n.g), an unusual euornithopod dinosaur from the latest Cretaceous of Romania. Journal of Systematic Palaeontology 1:65 - 123.

Wenwei, Y., R. A. Fortey, and S. T. Turvey. 2006. Ontogeny and relationships of the trilobite Pseudopetigurus Prantl and Přibyl. Palaeontology 49:537 - 546.

Werdelin, L., and N. Solounias. 1991. The Hyaenidae: taxonomic systematics and evolution. Fossils and Strata 30:1 - 104.

Wesley-Hunt, G. D., and J. J. Flynn. 2005. Phylogeny of the Carnivora: basal relationships among the carnivoramorphans, and assessment of the position of "Miacoidea" relative to crown-clade Carnivora. Journal of Systematic Palaeontology 3:1 - 28.

Westrop, S. R., R. Ludvigsen, and C. H. Kindle. 1996. Marjuman (Cambrian) agnostoid trilobites of the Cow Head Group, western Newfoundland. Journal of Paleontology 70:804 - 829.

Whitlock, J. A. 2011. A phylogenetic analysis of Diplodocoidea (Saurischia: Sauropoda). Zoological Journal of the Linnean Society 161:872-915.

Wickström, L. M., and P. C. J. Donoghue. 2005. Cladograms, phylogenies and the veracity of the conodont fossil record. Special Papers in Palaeontology 73:185 - 218.

Wilkinson, L. E., M. T. Young, and M. J. Benton. 2008. A new metriorhynchid crocodile (Mesoeucrocodylia: Thalattosuchia) from the Kimmeridgian (Upper Jurassic) of Wiltshire, UK. Palaeontology 51:1307-1333.

Williamson, T. E., and T. D. Carr. 2007. Bomburia and Ellipsodon (Mammalia: Mioclaenidae) from the Early Paleocene of New Mexico. Journal of Paleontology 81:966-985.

Wilson, M. V. H., and A. M. Murray. 2008. Osteoglossomorpha: phylogeny, biogeography, and fossil record and the significance of key African and Chinese fossil taxa. Geological Society, London, Special Publications 295:185-219.

Wu, X.-c., D. B. Brinkman, D. A. Eberth, and D. R. Braman. 2007. A new ceratopsid dinosaur (Ornithischia) from the uppermost Horseshoe Canyon Formation (upper Maastrichtian), Alberta, Canada. Canadian Journal of Earth Sciences 44:1243-1265. 
Xu, G.-H., and K.-Q. Gao. 2011. A new scanilepiform from the Lower Triassic of northern Gansu Province, China, and phylogenetic relationships of nonteleostean Actinopterygii. Zoological Journal of the Linnean Society 161:595612.

Xu, X., Y.-N. Cheng, X.-L. Wang, and C.-H. Chang. 2002a. An unusual oviraptorosaurian dinosaur from China. Nature 419:291 - 293.

Xu, X., M. A. Norell, X.-l. Wang, P. J. Makovicky, and X.-c. Wu. 2002b. A basal troodontid from the Early Cretaceous of China. Nature 415:780-784.

Yacobucci, M. M. 1999. Plasticity of developmental timing as the underlying cause of high speciation rates in ammonoids. An example from the Cenomanian Western Interior Seaway of North America. Pp. 59 - 77 in F. Olóriz and F. J. Rodriguez-Tovar, eds. Advancing research on living and fossil cephalopods. Kluwer Academic / Plenum, New York.

Yates, A. M. 2003. A new species of the primitive dinosaur Thecodontosaurus (Saurischia: Sauropodomorpha) and its implications for the systematics of early dinosaurs. Journal of Systematic Palaeontology 1:1-42.

Young, M. T., and M. B. De Andrade. 2009. What is Geosaurus? Redescription of Geosaurus giganteus (Thalattosuchia: Metriorhynchidae) from the Upper Jurassic of Bayern, Germany. Zoological Journal of the Linnean Society 157:551-585.

Zaher, H., D. Pol, A. B. Carvalho, C. Riccomini, D. Campos, and W. Nava. 2006. Redescription of the cranial morphology of Mariliasuchus amarali, and its phylogenetic affinities (Crocodyliformes, Notosuchia). American Museum Novitates 3512:1 - 40.

Zhao, X., Z. Cheng, X. Xu, and P. J. Makovicky. 2006. A new ceratopsian from the Upper Jurassic Houcheng Formation of Hebei, China. Acta Geologica Sinica 80:467 - 473.

Zheng, X., X. Xu, H. You, Q. Zhao, and Z. Dong. 2010. A short-armed dromaeosaurid from the Jehol Group of China with implications for early dromaeosaurid evolution. Proceedings of the Royal Society B: Biological Sciences 277:211-217.

Zhu, M., X. Yu, and P. E. Ahlberg. 2001. A primitive sarcopterygian fish with an eyestalk. Nature 410:81 - 84 .

ACKNOWLEDGEMENTS

For comments and discussion, I thank D. H. Erwin \& S. K. Lyons. This is Paleobiology Database Publication XXX.

\section{Supplementary Materials:}

Supplementary Figures \& Tables repeating analyses looking at disparity at $S / 3$. 


\section{Figures S1-S2}

\section{Tables S1-S4}

Appendix S1. Full results for 257 clades. 

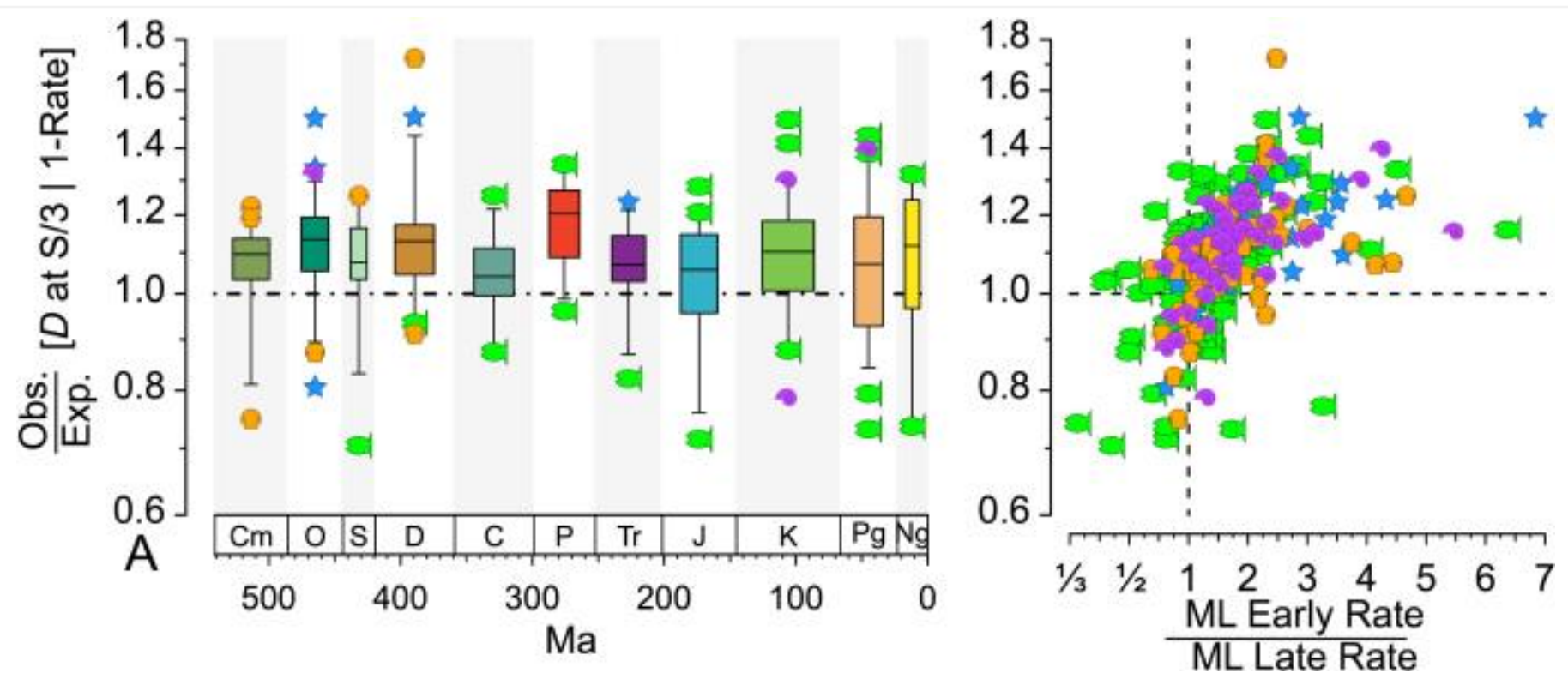

Fig. S1. Deviations from expected disparity $(D)$ among the first $S / 3$ of $S$ taxa given the expectations of uniform rates of independent change. Deviations are on a $\log$-scale so that half of expected $D$ is the same distance from 1.0 as twice expected $D$. For each clade, the uniform rate model maximizes the probability of observed character compatibility. (A) Deviations over time. $\tau=-0.037, p=0.403$. (B) Molluscs+Brachiopods (purple shells): $\tau=0.493, p=6.0 \times 10^{-7}$; Arthropods (orange trilobites): $\tau=0.391$, $p=5.0 \times 10^{-5}$; Echinoderms (blue stars): $\tau=0.516, p=1.8 \times 10^{-6}$; Chordates (green fishes): $\tau=0.414$, $p=2.5 \times 10^{-11}$. 

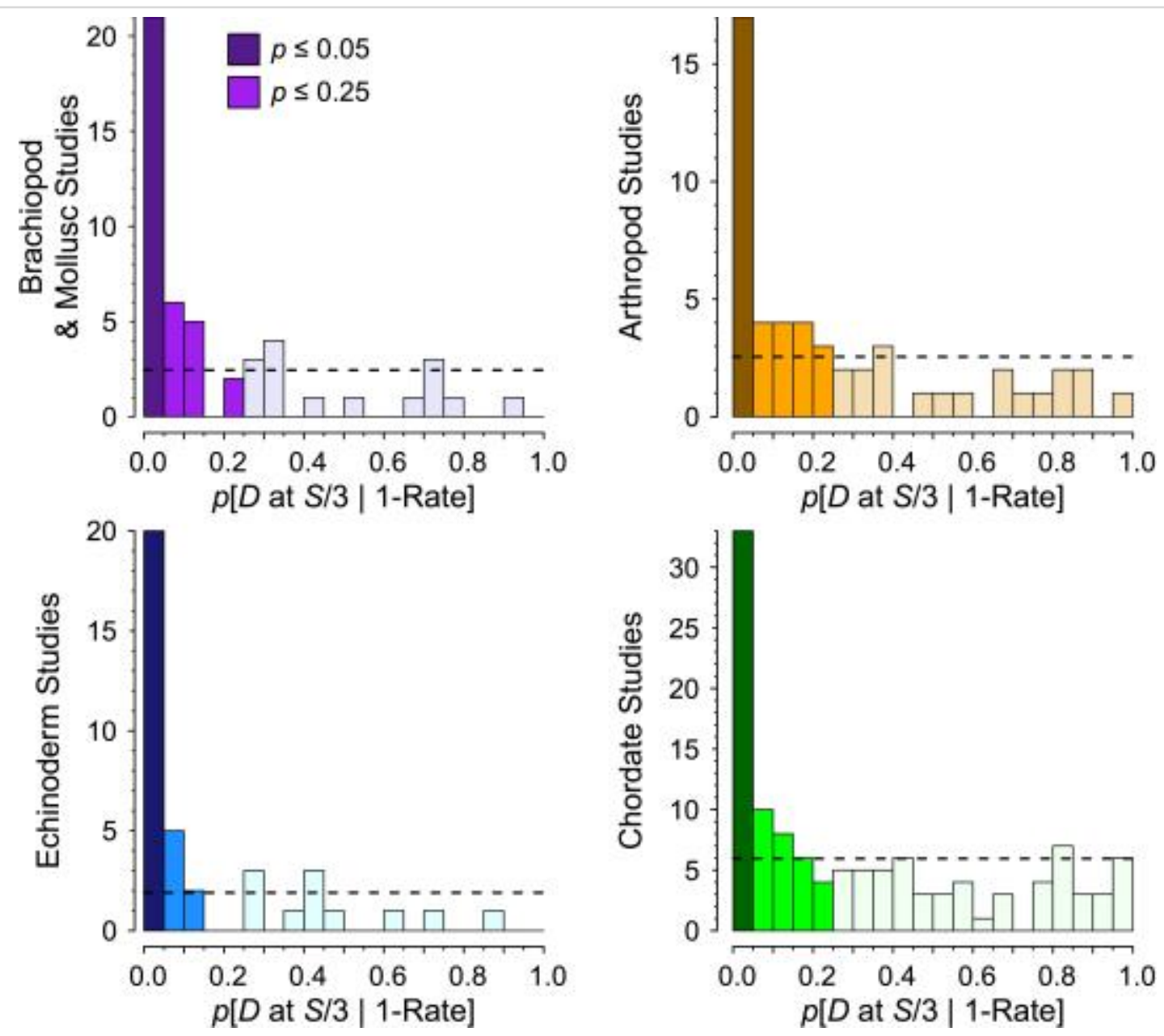

Fig. S2. Probabilities of observed disparity $(D)$ accumulated during the first half of clade evolution $(S / 3)$ given the best-fit uniform rate of independent change for all $S$ taxa in each clade. Significance based on 1000 Monte Carlo replications. Best-fit uniform rates maximize the probability of observed character compatibility for all $S$ taxa. Dashed lines show the expected number of studies at each $p$-value. 

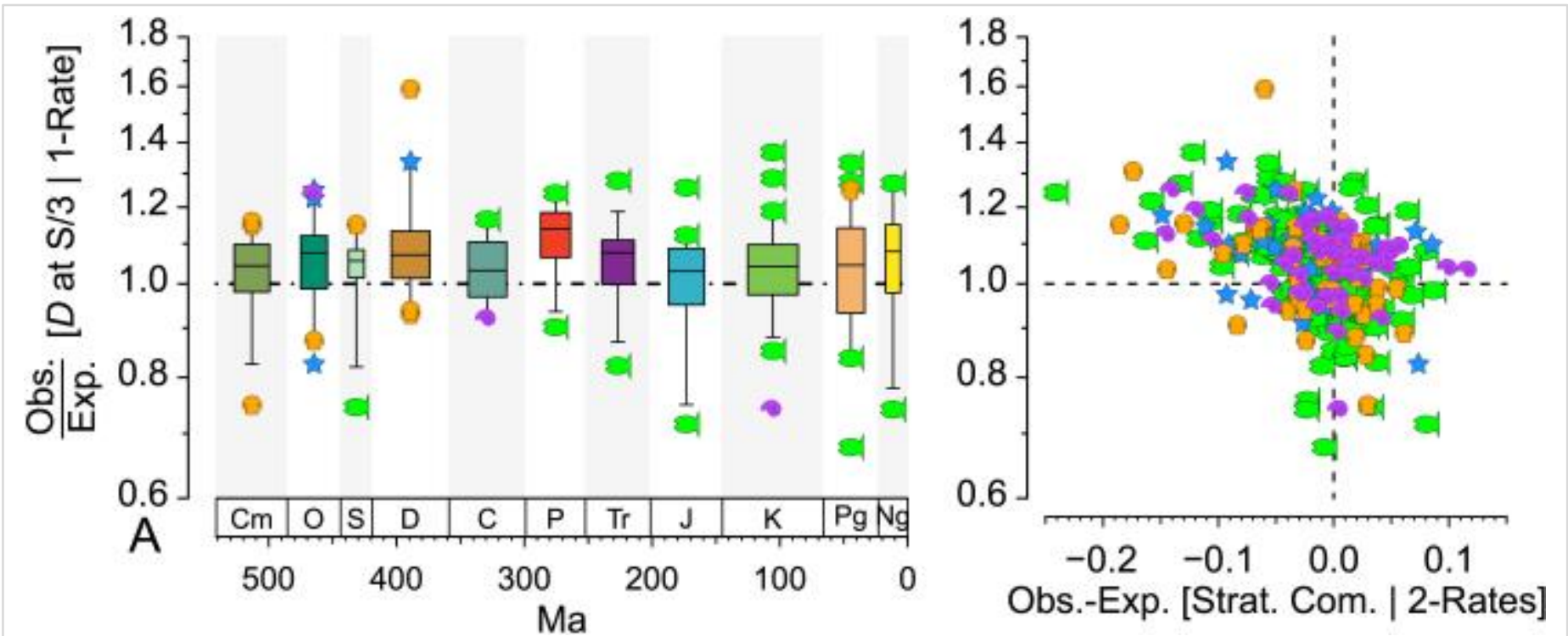

Fig. S3. Deviations from expected disparity $(D)$ among the first $S / 3$ of $S$ taxa given the expectations of separate early and late rates of independent change. Deviations are on a log-scale so that half of expected $D$ is the same distance from 1.0 as twice expected $D$. For each clade, the uniform rate model maximizes the probability of observed character compatibility among the first $S / 3$ taxa. (A) Deviations over time. $\tau=-0.034, p=0.429$. (B) Deviations vs deviations from expected stratigraphic compatibility. Molluscs+Brachiopods (purple shells): $\tau=-0.227, p=0.021$; Arthropods (orange trilobites): $\tau=-0.309$, $p=1.3 \times 10^{-3}$; Echinoderms (blue stars): $\tau=-0.138, p=0.223$; Chordates (green fishes): $\tau=0.315, p=3.7 \times 10^{-7}$. 

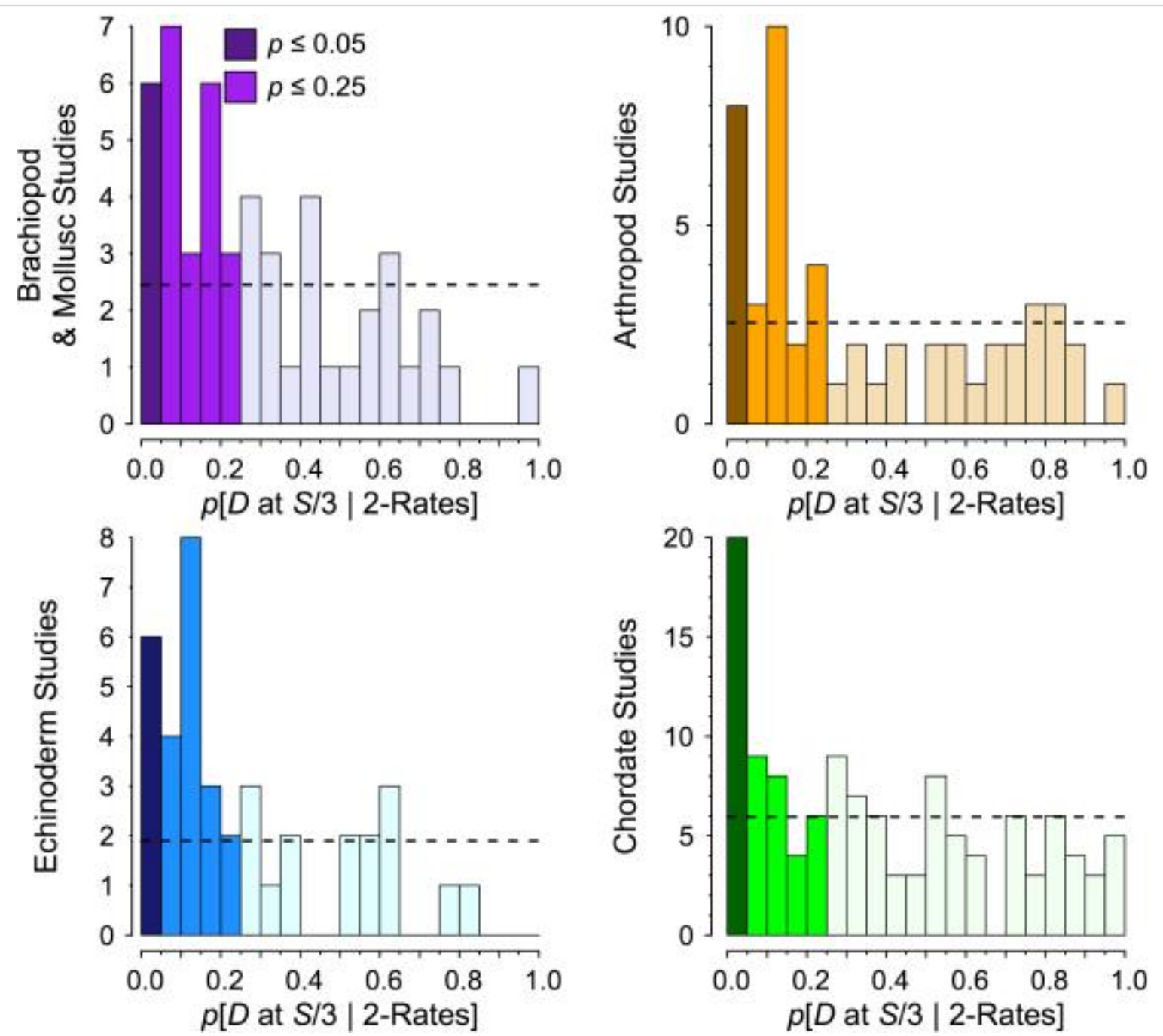

Fig. S4. Probabilities of observed disparity $(D)$ accumulated during the first half of clade evolution $(S / 3)$ given the best-fit "early" and "late" rates of independent change.

Significance based on 1000 Monte Carlo replications. Best-fit "early" rates maximize the probability of observed character compatibility for the first $S / 3$ taxa in a clade of $S$ taxa, with the best-fit "late" rate maximizing the probability of observed character compatibility for the whole clade following that early rate. Dashed lines show the expected number of studies at each $p$-value. 
Table S1. Deviations from expected disparity at $S / 3$ taxa within major taxonomic groups. "Studies" refers to the number of published matrices represent clades used. "Excess" gives the number of studies with excess disparity in the first half of clade evolution given a single rate ("1-Rate") and given separate early and late rates ("2-Rates"), with the early rate maximizing the probability of character compatibility given the earliest $S / 3$ of $S$ total taxa. The significance is the binomial probability of that many excess cases given the total studies and an expectation of $50 \%$. " $\sum R$ " gives the signed rank statistic, which ranks deviations by absolute values but then gives each rank $\mathrm{a}+/$ - based on the original statistic. Deviations are ranked after log-transformation, so half the expected disparity has the same rank as twice the expected disparity. Significance is assessed on the expectation that $\sum R=0$.

\begin{tabular}{lccccccccc} 
& \multicolumn{2}{c}{ 1-Rate } & \multicolumn{2}{c}{ 1-Rate } & \multicolumn{2}{c}{ 2-Rates } & \multicolumn{2}{c}{ 2-Rates } \\
\hline Taxa & Studies & Excess & $p$ & $\sum R$ & $p$ & Excess & $p$ & $\sum R$ & $p$ \\
\hline Brachiopods & & & & & & & & & \\
$\quad+$ Molluscs & 49 & 42 & $5.7 \times 10^{-8}$ & 979 & $5.6 \times 10^{-7}$ & 38 & $3.9 \times 10^{-5}$ & 817 & $1.3 \times 10^{-4}$ \\
Arthropods & 51 & 40 & $1.5 \times 10^{-5}$ & 868 & $2.4 \times 10^{-5}$ & 33 & 0.024 & 578 & 0.015 \\
Echinoderms & 38 & 35 & $5.4 \times 10^{-9}$ & 651 & $1.2 \times 10^{-6}$ & 29 & $2.4 \times 10^{-4}$ & 555 & $2.4 \times 10^{-5}$ \\
Chordates & 119 & 85 & $1.3 \times 10^{-6}$ & 3510 & $1.6 \times 10^{-6}$ & 75 & $3.2 \times 10^{-3}$ & 2432 & $6.4 \times 10^{-3}$
\end{tabular}


Table S2. Deviations from expected disparity at $S / 3$ over time. "Periods" give geochronological periods of the plurality of taxa within any one clade. "Studies" refers to the number of published matrices represent clades used. "Excess" gives the number of studies with excess disparity in the first half of clade evolution given a single rate ("1-Rate") and given separate early and late rates ("2-Rates"), with the early rate maximizing the probability of character compatibility given the earliest $S / 3$ of $S$ total taxa. The significance is the binomial probability of that many excess cases given the total studies and an expectation of 50\%. " $\sum R$ " gives the signed rank statistic, which ranks deviations by absolute values but then gives each rank $\mathrm{a}+/$ - based on the original statistic. Deviations are ranked after log-transformation, so half the expected disparity has the same rank as twice the expected disparity. Significance is assessed on the expectation that $\sum R=0$.

\begin{tabular}{lccccccccc} 
& \multicolumn{4}{c}{ 1-Rate } & \multicolumn{2}{c}{ 1-Rate } & \multicolumn{2}{c}{ 2-Rates } & \multicolumn{2}{c}{ 2-Rates } \\
\hline Period & Studies & Excess & $p$ & $\sum R$ & $p$ & Excess & $p$ & $\sum R$ & $p$ \\
Cambrian & 21 & 17 & $3.6 \times 10^{-3}$ & 135 & $9.5 \times 10^{-3}$ & 14 & 0.095 & 87 & 0.065 \\
Ordovician & 42 & 36 & $1.4 \times 10^{-6}$ & 727 & $2.7 \times 10^{-6}$ & 31 & $1.4 \times 10^{-3}$ & 573 & $1.7 \times 10^{-4}$ \\
Silurian & 14 & 11 & 0.029 & 67 & 0.018 & 11 & 0.029 & 47 & 0.070 \\
Devonian & 29 & 26 & $7.6 \times 10^{-6}$ & 389 & $1.3 \times 10^{-5}$ & 24 & $2.7 \mathrm{E}-4$ & 337 & $1.3 \times 10^{-4}$ \\
Carboniferous & 12 & 9 & 0.073 & 32 & 0.105 & 7 & 0.387 & 30 & 0.120 \\
Permian & 11 & 10 & $5.9 \times 10^{-3}$ & 62 & $2.9 \times 10^{-3}$ & 9 & 0.033 & 56 & $6.4 \times 10^{-3}$ \\
Triassic & 16 & 13 & 0.011 & 70 & 0.035 & 12 & 0.038 & 72 & 0.031 \\
Jurassic & 21 & 14 & 0.095 & 87 & 0.065 & 12 & 0.332 & 45 & 0.217 \\
Cretaceous & 38 & 29 & $8.3 \times 10^{-4}$ & 525 & $7.0 \times 10^{-5}$ & 21 & 0.314 & 295 & 0.016 \\
Paleogene & 41 & 28 & 0.014 & 425 & $2.9 \times 10^{-3}$ & 25 & 0.106 & 265 & 0.043 \\
Neogene & 12 & 9 & 0.073 & 28 & 0.136 & 9 & 0.073 & 26 & 0.154
\end{tabular}


Appendix S1. Data sets, disparity and expectations from Monte Carlo tests.

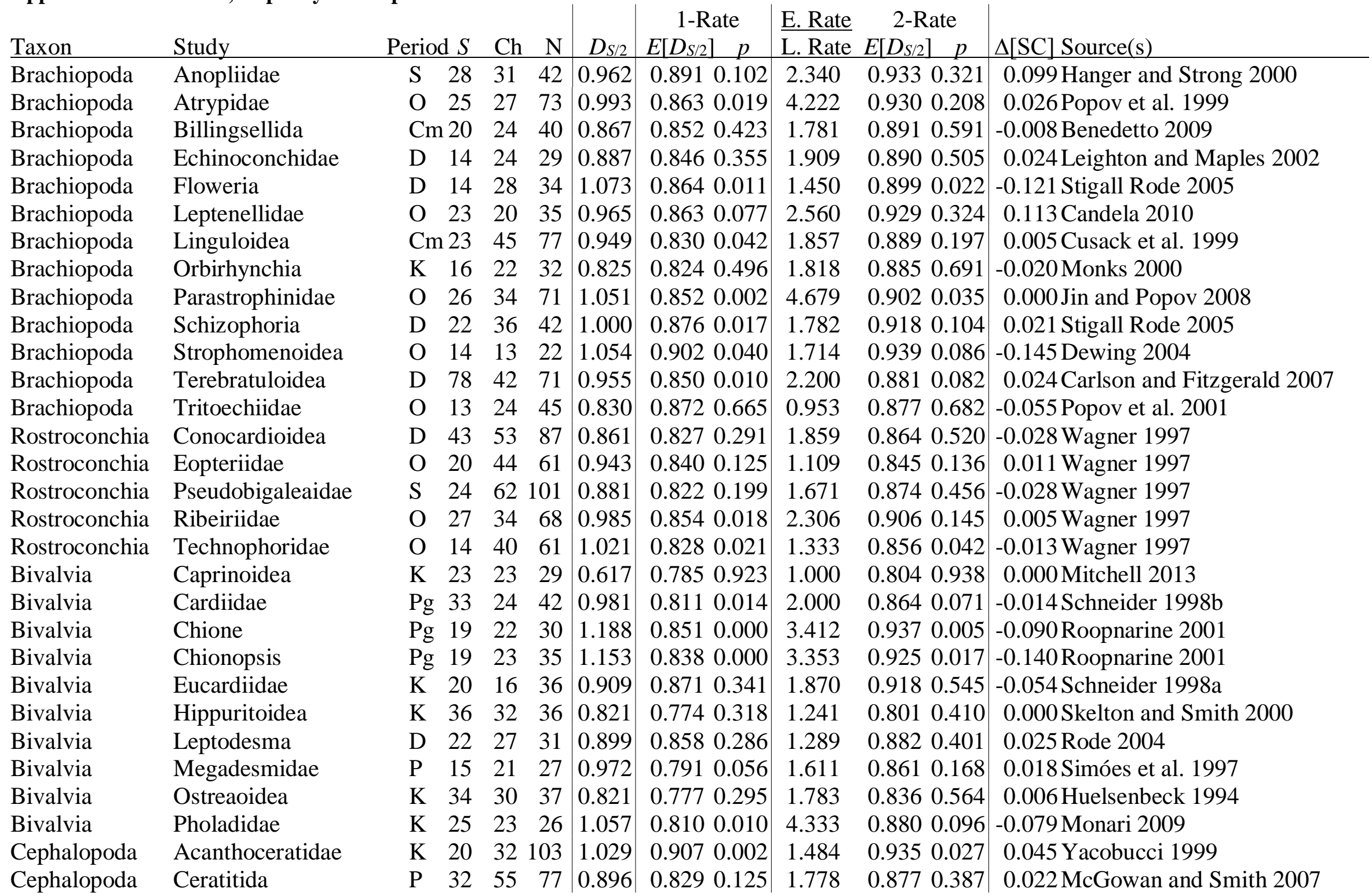




\begin{tabular}{|c|c|c|c|c|c|c|c|c|c|}
\hline Taxon & Study & Period $S$ & $\mathrm{Ch}$ & $\mathrm{N}$ & $D_{S / 2}$ & $\begin{array}{c}\text { 1-Rate } \\
E\left[D_{S / 2}\right] p\end{array}$ & $\frac{\text { E. Rate }}{\text { L. Rate }}$ & $\begin{array}{c}\text { 2-Rate } \\
E\left[D_{S / 2}\right] p\end{array}$ & $\Delta[\mathrm{SC}]$ Source $(\mathrm{s})$ \\
\hline Cephalopoda & Hamitidae & K 27 & 30 & 43 & 0.691 & 0.7710 .757 & 1.500 & 0.8180 .885 & 0.013 Monks 2002 \\
\hline Cephalopoda & Scaphitacoidea & K 13 & 18 & 23 & 0.869 & 0.7550 .232 & 1.818 & 0.8780 .520 & 0.053 Monks 2000 \\
\hline Cephalopoda & Turrilitoidea & K 26 & 26 & 29 & 0.929 & 0.7680 .065 & 1.882 & 0.8350 .240 & 0.041 Monks 1999 \\
\hline Tergomya & Cyrtonelloidea & O 21 & 41 & 68 & 1.081 & 0.8180 .001 & 3.600 & 0.8820 .024 & -0.034 Wagner 2001 \\
\hline Gastropoda & Columbellidae & $\mathrm{Ng} 24$ & 30 & 43 & 0.946 & 0.8400 .101 & 1.452 & 0.8630 .148 & 0.041 de Maintenon 2005 \\
\hline Gastropoda & Eotomarioidea & $\mathrm{O} \quad 40$ & 69 & 137 & 0.904 & 0.8150 .062 & 1.812 & 0.8540 .227 & -0.044 Wagner $1999 b$ \\
\hline Gastropoda & Harpidae & $\operatorname{Pg} 18$ & 28 & 43 & 0.836 & 0.7890 .325 & 2.150 & 0.8440 .527 & -0.091 Merle and Pacaud 2003 \\
\hline Gastropoda & Hormotomidae & O 34 & 67 & 122 & 0.950 & 0.8090 .019 & 1.805 & 0.8510 .094 & -0.006 Wagner $1999 b$ \\
\hline Gastropoda & Macluritidae & O 18 & 50 & 84 & 0.939 & 0.8460 .114 & 1.538 & 0.8750 .215 & -0.014 Wagner $1999 b$ \\
\hline Gastropoda & Nassariidae & $\operatorname{Pg} 26$ & 25 & 36 & 0.959 & 0.8370 .046 & 1.697 & 0.8750 .150 & -0.042 Haasl 2000 \\
\hline Gastropoda & Tropidodiscidae & O 22 & 33 & 57 & 1.019 & 0.8260 .012 & 2.182 & 0.8660 .053 & -0.025 Wagner 2001 \\
\hline Trilobita & Agnostoidea & $\mathrm{Cm} 82$ & 80 & 113 & 0.980 & 0.8220 .003 & 1.650 & 0.8380 .005 & 0.006 Cotton and Fortey 2005 \\
\hline Trilobita & Agnostoidea & $\mathrm{Cm} 43$ & 28 & 43 & 0.986 & 0.8440 .008 & 2.200 & 0.8770 .046 & -0.003 Westrop et al. 1996 \\
\hline Trilobita & Alokistocaridae & $\mathrm{Cm} 19$ & 50 & 101 & 1.020 & 0.8930 .017 & 2.139 & 0.9360 .117 & -0.040 Sundberg 1999 \\
\hline Trilobita & Basal Trilobita & $\mathrm{Cm} 16$ & 29 & 40 & 0.927 & 0.8510 .184 & 0.514 & 0.8020 .095 & 0.007 Lieberman 2002 \\
\hline Trilobita & Burlingiidae & $\mathrm{Cm} 16$ & 18 & 18 & 0.658 & 0.8770 .984 & 0.600 & 0.8320 .944 & 0.008 Ebbestad and Budd 2002 \\
\hline Trilobita & Emuellidae & $\mathrm{Cm} 15$ & 34 & 37 & 0.674 & 0.8250 .899 & 0.818 & 0.8250 .899 & 0.037 Paterson and Edgecombe 2006 \\
\hline Trilobita & Iwayaspidinae & $\mathrm{Cm} 14$ & 23 & 30 & 0.920 & 0.8810 .331 & 2.455 & 0.9330 .551 & 0.054 Hughes and Rushton 1990 \\
\hline Trilobita & Kochaspidae & $\mathrm{Cm} 66$ & 70 & 149 & 0.960 & 0.8570 .007 & 2.255 & 0.9190 .160 & 0.010 Sundberg 2004 \\
\hline Trilobita & Missisquoiidae & $\mathrm{Cm} 22$ & 40 & 58 & 0.880 & 0.8880 .555 & 1.083 & 0.9000 .632 & -0.040 Lee et al. 2008 \\
\hline Trilobita & Nevadoidea & $\mathrm{Cm} 22$ & 57 & 80 & 0.981 & 0.8880 .077 & 0.852 & 0.8830 .072 & 0.017 Lieberman 2001 \\
\hline
\end{tabular}




\begin{tabular}{|c|c|c|c|c|c|c|c|c|c|c|}
\hline Taxon & Study & \multicolumn{2}{|c|}{ Period $S$} & $\mathrm{Ch}$ & $\mathrm{N}$ & $D_{S / 2}$ & $\begin{array}{c}\text { 1-Rate } \\
E\left[D_{S / 2}\right] p\end{array}$ & $\begin{array}{l}\text { E. Rate } \\
\text { L. Rate }\end{array}$ & $\begin{array}{c}\text { 2-Rate } \\
E\left[D_{S / 2}\right] p\end{array}$ & $\Delta[\mathrm{SC}]$ Source $(\mathrm{s})$ \\
\hline Trilobita & Oryctocephalinae & \multicolumn{2}{|c|}{$\mathrm{Cm} 24$} & 20 & 42 & 1.056 & 0.8640 .003 & 2.063 & 0.9230 .027 & -0.022 Sundberg 2006 \\
\hline Trilobita & Polymeroidea & \multicolumn{2}{|c|}{$\mathrm{Cm} 19$} & 26 & 41 & 0.719 & 0.7890 .728 & 1.296 & 0.8300 .850 & 0.024 Babcock 1994 \\
\hline Trilobita & Pterocephaliidae & \multicolumn{2}{|c|}{$\mathrm{Cm} 36$} & 45 & 71 & 0.861 & 0.8250 .289 & 1.731 & 0.8610 .506 & -0.001 Hopkins 2011 \\
\hline Trilobita & Ptychoparioidea & \multicolumn{2}{|c|}{$\mathrm{Cm} 48$} & 72 & 113 & 0.912 & 0.8130 .066 & 2.256 & 0.8490 .194 & -0.003 Cotton 2001 \\
\hline Trilobita & Wuaniidae & \multicolumn{2}{|c|}{$\mathrm{Cm} 37$} & 14 & 25 & 0.931 & 0.8780 .187 & 1.146 & 0.8950 .245 & 0.000 Bentley and Jago 2004 \\
\hline Trilobita & Acanthoparyphinae & $\mathrm{O}$ & 24 & 39 & 50 & 0.692 & 0.7920 .881 & 1.333 & 0.8270 .944 & -0.020 Adrain 1998 \\
\hline Trilobita & Deiphoninae & $\mathrm{O}$ & 21 & 27 & 29 & 0.787 & 0.8660 .824 & 0.920 & 0.8750 .849 & -0.083 Congreve and Lieberman 2010 \\
\hline Trilobita & Dimeropygidae & $\mathrm{O}$ & 18 & 25 & 35 & 0.836 & 0.8070 .370 & 5.778 & 0.9440 .773 & 0.057 Adrain et al. 2001 \\
\hline Trilobita & Illaenidae & $\mathrm{O}$ & 28 & 20 & 40 & 1.053 & 0.8470 .003 & 3.421 & 0.8920 .030 & -0.134 Amati et al. 2004 \\
\hline Trilobita & Pseudopetigurus & $\mathrm{O}$ & 17 & 25 & 40 & 0.911 & 0.8730 .330 & 1.225 & 0.8880 .395 & -0.137 Wenwei et al. 2006 \\
\hline Trilobita & Reedocalymeninae & $\mathrm{O}$ & 32 & 25 & 33 & 0.831 & 0.8400 .546 & 0.882 & $\begin{array}{lll}0.831 & 0.499\end{array}$ & -0.037 Turvey 2002 \\
\hline Trilobita & Shumardiidae & $\mathrm{O}$ & 33 & 52 & 99 & 0.867 & 0.8620 .453 & 1.197 & 0.8840 .634 & 0.039 Waisfeld et al. 2001 \\
\hline Trilobita & Sphaerexochinae & $\mathrm{O}$ & 31 & 39 & 46 & 0.902 & 0.8560 .234 & 2.133 & 0.9130 .564 & 0.012 Congreve and Lieberman 2011 \\
\hline Trilobita & Toernquistiidae & $\mathrm{O}$ & 38 & 55 & 85 & 0.851 & 0.8420 .438 & 1.216 & 0.8640 .610 & -0.004 Chatterton et al. 1998 \\
\hline Trilobita & Acanthopgye & $\mathrm{S}$ & 25 & 15 & 23 & 0.954 & 0.8930 .203 & 1.815 & 0.9210 .321 & -0.059 Ebach and Ahyong 2001 \\
\hline Trilobita & Encrinurinae & S & 32 & 40 & 56 & 0.997 & 0.7980 .002 & 3.069 & 0.8990 .125 & -0.057 Adrain and Edgecombe 1997 \\
\hline Trilobita & Odontopleuridae & $S$ & 62 & 35 & 57 & 0.954 & 0.8280 .009 & 1.190 & 0.8410 .018 & -0.106 Ramsköld and Chatterton 1991 \\
\hline Trilobita & Phacopidae & $\mathrm{S}$ & 50 & 32 & 86 & 0.826 & 0.8650 .748 & 2.000 & 0.8880 .849 & $\begin{array}{l}\text { 0.008 Ramsköld and Werdelin 1991; } \\
\text { Edgecombe and Ramsköld 1994; } \\
\text { Ebach } 2002\end{array}$ \\
\hline Trilobita & Trochurinae & S & 19 & 21 & 37 & 0.815 & 0.8610 .710 & 1.175 & 0.8870 .825 & 0.045 Campbell and Chatterton 2007 \\
\hline Trilobita & Asteropyginae & $\mathrm{D}$ & 38 & 66 & 104 & 0.988 & 0.8600 .006 & 2.490 & 0.8990 .085 & 0.008 Lieberman and Kloc 1997 \\
\hline Trilobita & Basidechenella & $\mathrm{D}$ & 16 & 25 & 32 & 1.144 & 0.8150 .000 & 2.182 & 0.8870 .009 & -0.171 Lieberman 1994 \\
\hline Trilobita & Dechenella & $\mathrm{D}$ & 17 & 47 & 68 & 1.043 & 0.8810 .010 & 1.917 & 0.9260 .063 & -0.066 Lieberman et al. 1991 \\
\hline Trilobita & Koneprusiinae & $\mathrm{D}$ & 39 & 23 & 32 & 0.921 & 0.8360 .110 & 1.226 & 0.8550 .160 & -0.055 Lieberman 1993 \\
\hline Trilobita & Malvinella & $\mathrm{D}$ & 14 & 51 & 61 & 0.993 & 0.8800 .085 & 1.388 & 0.9060 .146 & 0.021 Lieberman 1994 \\
\hline Trilobita & Metacryphaeus & $\mathrm{D}$ & 17 & 38 & 48 & 0.937 & 0.8320 .128 & 1.489 & 0.8550 .220 & 0.052 Adrain et al. 2008 \\
\hline Trilobita & Proetidae & $\mathrm{D}$ & 21 & 52 & 58 & 0.866 & 0.8250 .303 & 1.145 & 0.8440 .389 & 0.015 Lieberman 1994 \\
\hline Trilobita & Trimerocephalus & $\mathrm{D}$ & 14 & 23 & 33 & 1.347 & 0.7810 .000 & 5.714 & 0.9240 .013 & -0.035 Crônier 2003 \\
\hline Trilobita & Phillipsidae & $\mathrm{C}$ & 28 & 30 & 38 & 0.980 & 0.8900 .034 & 0.717 & 0.8660 .019 & -0.083 Brezinski 2003; 2005 \\
\hline Trilobita & Lichoidea & $\mathrm{O}$ & 36 & 48 & 89 & $|0.995|$ & 0.8540 .006 & 2.025 & 0.9020 .065 & -0.009 Pollitt et al. 2005 \\
\hline
\end{tabular}




\begin{tabular}{|c|c|c|c|c|c|c|c|c|c|c|}
\hline Taxon & Study & Perio & $\mathrm{d} S$ & $\mathrm{Ch}$ & $\mathrm{N}$ & $D_{S / 2}$ & $\begin{array}{c}\text { 1-Rate } \\
E\left[D_{S / 2}\right] p\end{array}$ & $\frac{\text { E. Rate }}{\text { L. Rate }}$ & $\begin{array}{c}\text { 2-Rate } \\
E\left[D_{S / 2}\right] p\end{array}$ & $\Delta[\mathrm{SC}]$ Source $(\mathrm{s})$ \\
\hline Chelicerata & Early Arachnomorpha & $\mathrm{a} \mathrm{Cn}$ & 24 & 38 & 51 & 0.879 & 0.7890 .172 & 1.417 & 0.8170 .270 & -0.024 Cotton and Braddy 2003 \\
\hline Chelicerata & Eurypetriidae & $\mathrm{S}$ & 23 & 33 & 63 & 0.947 & 0.8510 .125 & 1.067 & 0.8640 .154 & -0.022 Tetlie and Cuggy 2007 \\
\hline Chelicerata & Eurypterus & $\mathrm{S}$ & 13 & 20 & 27 & 1.021 & 0.8320 .117 & 1.500 & 0.8910 .208 & -0.188 Tetlie 2006 \\
\hline Chelicerata & Stylonurina & $\mathrm{S}$ & 23 & 45 & 45 & 0.887 & 0.7590 .127 & 1.222 & 0.7950 .191 & 0.019Lamsdell et al. 2010 \\
\hline Crustacea & Astacidae & $\mathrm{J}$ & 17 & 28 & 45 & 0.841 & 0.8790 .675 & 1.091 & 0.8930 .740 & 0.023 Rode and Babcock 2003 \\
\hline Crustacea & Astacoidea & $\mathrm{J}$ & 23 & 21 & 39 & 0.831 & 0.8160 .450 & 1.194 & 0.8490 .574 & 0.001 Amati and Westrop 2004 \\
\hline Crustacea & Beyrichiocopa & $\mathrm{O}$ & 34 & 39 & 48 & 0.902 & 0.7700 .069 & 1.412 & 0.8020 .131 & -0.008 Tinn and Meidla 2004 \\
\hline Crustacea & Phyllocarida & $\mathrm{D}$ & 41 & 54 & 83 & 0.872 & 0.8130 .158 & 1.938 & 0.8800 .547 & -0.051 Rode and Lieberman 2002 \\
\hline Crustacea & Thylacocephala & $\mathrm{D}$ & 18 & 15 & 36 & 0.802 & 0.8760 .816 & 1.083 & 0.8860 .853 & 0.034 Schram et al. 1999 \\
\hline Crustacea & Xanthoidea & $\mathrm{Pg}$ & 21 & 62 & 64 & 1.075 & 0.7800 .000 & 6.353 & 0.9080 .123 & -0.028 Karasawa and Schweitzer 2006 \\
\hline Cincta & Cincta & $\mathrm{Cn}$ & 21 & 56 & 79 & 0.875 & 0.7920 .146 & 1.262 & 0.8300 .274 & -0.012 Smith and Zamora 2009 \\
\hline Stylophora & Anomalocystitidae & $\mathrm{O}$ & 20 & 97 & 97 & 0.993 & 0.8290 .004 & 1.935 & 0.8940 .093 & 0.005 Ruta 1999 \\
\hline Stylophora & Cornuta & $\mathrm{O}$ & 32 & 72 & 78 & 0.941 & 0.7860 .010 & 1.770 & 0.8490 .130 & -0.065 Cripps 1991 \\
\hline Stylophora & Cornuta & $\mathrm{O}$ & 22 & 34 & 34 & 0.968 & 0.7630 .028 & 1.727 & 0.8350 .119 & -0.026Daley 1992 \\
\hline Stylophora & Cornuta & $\mathrm{O}$ & 28 & 18 & 36 & 0.876 & 0.8310 .276 & 2.000 & 0.8950 .594 & -0.080 Lefebvre 2001 \\
\hline Stylophora & Dendrocystitidae & $\mathrm{O}$ & 15 & 16 & 25 & 0.915 & 0.8530 .259 & 0.778 & 0.8480 .259 & -0.041 Parsley 1997; Parsley and Sumrall 2007 \\
\hline Stylophora & Mitrata & $\mathrm{O}$ & 13 & 38 & 44 & 0.841 & 0.7690 .291 & 5.556 & 0.8780 .567 & -0.085 Ruta and Theron 1997 \\
\hline Stylophora & Mitrata & $\mathrm{O}$ & 17 & 76 & 134 & 0.927 & 0.8200 .085 & 2.388 & 0.9070 .409 & 0.008 Ruta 1997 \\
\hline Stylophora & Stylophora & $\mathrm{O}$ & 42 & 42 & 91 & 0.889 & 0.8180 .139 & 1.300 & 0.8330 .195 & 0.019 Parsley 1997 \\
\hline Edrioasteroidea & Edrioasteroidea & $\mathrm{O}$ & 15 & 24 & 27 & 0.640 & 0.7880 .846 & 1.150 & 0.8060 .872 & 0.077 Sumrall and Gahn 2006 \\
\hline Edrioasteroidea & Isorophida & $\mathrm{O}$ & 13 & 23 & 24 & 1.194 & 0.7890 .001 & 5.833 & 0.9130 .050 & -0.071 Sumrall and Zamora 2011 \\
\hline Asterozoa & Asterozoa & $\mathrm{O}$ & 36 & 142 & 156 & 1.017 & 0.7670 .000 & 2.151 & 0.8100 .009 & -0.016 Dean Shackleton 2005 \\
\hline Asterozoa & Goniasteridae & $\mathrm{J}$ & 21 & 68 & 71 & 0.851 & 0.8320 .417 & 1.182 & 0.8640 .573 & 0.034 Blake 2010 \\
\hline Blastozoa & Blastoidea & $\mathrm{D}$ & 68 & 93 & 153 & 0.910 & 0.8060 .029 & 2.100 & 0.8560 .193 & 0.024 Bodenbender 1995 \\
\hline Blastozoa & Pleurocystitidae & $\mathrm{D}$ & 13 & 21 & 24 & 1.180 & 0.7840 .002 & 5.333 & 0.8990 .056 & $\begin{array}{c}\text {-0.087 Sumrall and Sprinkle 1995; } \\
\text { Parsley and Sumrall 2007; } \\
\text { Nardin and Bohatý } 2013\end{array}$ \\
\hline Crinoidea & Basal Crinoidea & $\mathrm{O}$ & 33 & 25 & 69 & 1.013 & 0.8890 .008 & 2.472 & 0.9390 .097 & -0.037 Ausich 1998a \\
\hline Crinoidea & Botryocrinidae & $\mathrm{C}$ & 13 & 14 & 21 & 0.838 & 0.8240 .460 & 1.571 & 0.8950 .653 & -0.016 Gahn and Kammer 2002 \\
\hline Crinoidea & Calceocrinidae & $S$ & 22 & 17 & 32 & 1.027 & 0.8780 .012 & 1.100 & 0.8920 .031 & 0.072 Harvey and Ausich 1997 \\
\hline Crinoidea & Camerata & $\mathrm{O}$ & 28 & 27 & 72 & 1.028 & 0.8850 .003 & 1.845 & 0.9260 .035 & -0.017 Ausich 1998b \\
\hline
\end{tabular}




\begin{tabular}{|c|c|c|c|c|c|c|c|c|c|c|}
\hline Taxon & Study & Perio & $\mathrm{d} S$ & $\mathrm{Ch}$ & $\mathrm{N}$ & $D_{S / 2}$ & $\begin{array}{c}\text { 1-Rate } \\
E\left[D_{S / 2}\right] p\end{array}$ & $\begin{array}{l}\text { E. Rate } \\
\text { L. Rate }\end{array}$ & $\begin{array}{c}\text { 2-Rate } \\
E\left[D_{S / 2}\right] p\end{array}$ & $\Delta[\mathrm{SC}]$ Source $(\mathrm{s})$ \\
\hline Crinoidea & Cladida & $\mathrm{O}$ & 27 & 21 & 46 & 1.060 & 0.8270 .002 & 2.200 & 0.8930 .034 & -0.007 Ausich $1998 b$ \\
\hline Crinoidea & Cupulocrinidae & $\mathrm{O}$ & 13 & 19 & 34 & 1.002 & 0.8150 .048 & 4.300 & 0.9340 .337 & -0.090 Brower 2001 \\
\hline Crinoidea & Cyathocrinites & $\mathrm{C}$ & 14 & 14 & 17 & 0.787 & 0.8100 .578 & 0.941 & 0.8020 .553 & -0.022 Kammer and Gahn 2003 \\
\hline Crinoidea & Disparida & $\mathrm{O}$ & 45 & 31 & 77 & 0.965 & 0.8440 .021 & 1.678 & 0.8850 .097 & 0.011 Ausich 1998b \\
\hline Crinoidea & Pereichocrinidae & $\mathrm{D}$ & 20 & 32 & 42 & 1.035 & 0.8800 .011 & 3.097 & 0.9500 .147 & 0.088 Ausich and Kammer 2008 \\
\hline Echinoidea & Arbacoidea & $\mathrm{K}$ & 21 & 40 & 48 & 0.706 & 0.7630 .723 & 1.375 & 0.8140 .843 & -0.022 Smith and Wright 1993 \\
\hline Echinoidea & Arbacoidea & $\operatorname{Tr}$ & 25 & 26 & 41 & 1.052 & 0.8540 .004 & 1.938 & 0.8780 .015 & -0.153 Smith 1994 \\
\hline Echinoidea & Cassiduloidea & $\mathrm{K}$ & 69 & 38 & 57 & 0.808 & 0.7960 .417 & 1.745 & 0.8240 .575 & -0.008 Suter 1994 \\
\hline Echinoidea & Cassiduloidea & $\mathrm{K}$ & 49 & 31 & 47 & 0.947 & 0.7990 .017 & 2.533 & 0.8520 .107 & -0.087 Saucède and Neraudeau 2006 \\
\hline Echinoidea & Clypeasteroidea & $\mathrm{K}$ & 43 & 42 & 61 & 0.976 & 0.7860 .002 & 4.400 & 0.8750 .149 & -0.006 Smith 2001 \\
\hline Echinoidea & Disasteroidea & $\mathrm{K}$ & 26 & 19 & 28 & 0.941 & 0.8170 .093 & 1.320 & 0.8400 .138 & 0.033 Barras 2007 \\
\hline Echinoidea & Holasteroidea & $\mathrm{K}$ & 43 & 34 & 51 & 0.816 & 0.7980 .396 & 1.216 & 0.8190 .518 & -0.023 Smith 2004 \\
\hline Echinoidea & Irregularia & $\mathrm{J}$ & 27 & 37 & 50 & 0.968 & 0.8190 .020 & 2.026 & 0.8870 .154 & -0.091 Saucède et al. 2007 \\
\hline Echinoidea & Loveniidae & $\mathrm{Pg}$ & 14 & 38 & 61 & 1.003 & 0.9140 .093 & 1.385 & 0.9400 .178 & -0.047 Kroh 2007 \\
\hline Echinoidea & Mesozoic Echinoidea & $\operatorname{Tr}$ & 46 & 54 & 77 & 0.806 & 0.7830 .355 & 1.583 & 0.8170 .560 & 0.000 Smith 2007 \\
\hline Echinoidea & Somaliasteridae & $\mathrm{K}$ & 19 & 24 & 31 & 1.031 & 0.8060 .007 & 1.360 & 0.8480 .047 & -0.071 Jeffery 1999 \\
\hline Echinoidea & Spatangoidea & $\mathrm{Pg}$ & 50 & 68 & 104 & 0.892 & 0.7870 .049 & 1.859 & 0.8390 .248 & 0.022 Stockley et al. 2005 \\
\hline Echinoidea & Temnopleuridae & $\mathrm{Pg}$ & 16 & 36 & 47 & 1.074 & 0.8350 .004 & 1.889 & 0.8670 .021 & -0.038 Jeffery and Emlet 2003 \\
\hline Echinoidea & Toxasteridae & $\mathrm{J}$ & 35 & 35 & 62 & 0.963 & 0.8290 .014 & 1.377 & 0.8490 .033 & -0.039 Villier et al. 2004 \\
\hline Conodonta & Hindeodus-Isarcicella & $\mathrm{P}$ & 21 & 20 & 20 & 0.763 & 0.7930 .604 & 1.529 & 0.8510 .765 & 0.036 Jiang et al. 2011 \\
\hline Conodonta & Kockelella & $\mathrm{S}$ & 17 & 36 & 36 & 0.580 & 0.8240 .972 & 0.702 & 0.8140 .970 & 0.040 Wickström and Donoghue 2005 \\
\hline Conodonta & Palmatolepis & $\mathrm{D}$ & 15 & 25 & 26 & 0.755 & 0.7420 .469 & 1.846 & 0.8680 .743 & -0.002 Donoghue 2001 \\
\hline Cephalaspida & Thyestiidae & $S$ & 18 & 31 & 40 & 0.920 & 0.8950 .361 & 1.031 & 0.9080 .422 & -0.039 Sansom 2008 \\
\hline Placoderma & Pteraspidiformes & $\mathrm{D}$ & 26 & 59 & 98 & 1.002 & 0.8590 .011 & 1.804 & 0.8850 .025 & -0.082 Pernègre and Elliott 2008 \\
\hline Placoderma & Actinolepidae & $\mathrm{S}$ & 18 & 37 & 37 & 0.878 & 0.8120 .254 & 1.139 & 0.8270 .328 & 0.038 Johnson et al. 2000 \\
\hline Placoderma & Arthrodira & $\mathrm{D}$ & 31 & 54 & 56 & 0.814 & 0.8240 .538 & 0.656 & 0.8020 .446 & -0.012 Dupret 2004 \\
\hline Placoderma & Eubrachythoraci & $\mathrm{D}$ & 19 & 48 & 61 & 0.963 & 0.8850 .198 & 0.737 & 0.8800 .173 & 0.021 Carr and Hlavin 2010 \\
\hline Placoderma & Phyllolepidae & $\mathrm{D}$ & 38 & 63 & 64 & 0.755 & 0.8060 .756 & 0.504 & 0.7730 .581 & -0.042 Dupret and Zhu 2007 \\
\hline Actinopterygia & Amblypteridae & $\mathrm{C}$ & 50 & 57 & 90 & 0.903 & 0.8410 .105 & 1.748 & 0.8850 .384 & 0.017 Dietze 2000 \\
\hline Actinopterygia & Amiidae & $\mathrm{Pg}$ & 21 & 45 & 48 & $|1.019|$ & 0.7350 .013 & 4.636 & 0.8730 .201 & -0.054 Grande and Bemis 1998 \\
\hline
\end{tabular}


$\underline{\text { Taxon }}$

Study

1-Rate $\quad$ E. Rate 2-Rate

Actinopterygia Basal Teleostei

\begin{tabular}{lll|lllllll} 
Period $S$ & $C h$ & $\mathrm{~N}$ & $D_{S / 2}$ & $E\left[D_{S / 2}\right]$ & $p$ & L. Rate & $E\left[D_{S / 2}\right]$ & $p$ & $\Delta[\mathrm{SC}]$ Source(s)
\end{tabular}

Actinopterygia Palaeonisciformes

Actinopterygia Ginglymodi

Actinopterygia Osteoglossomorphes

Actinopterygia Perleidiformes

Actinopterygia Scanalepiformes

Actinopterygia Tetradontiformes

Sarcopterygia Basal Sarcopterygia

Sarcopterygia Basal Sarcopterygia

Sarcopterygia Coelocanthiformes

Sarcopterygia Coelocanthiformes

Sarcopterygia Devonian Dipnoi

Sarcopterygia Mesozoic Dipnoi

Sarcopterygia Rhipidistia

Tetrapoda Early Tetrapoda

Temnospondyla Brachyopoidea

Temnospondyla Branchiosauridae

Temnospondyla Capitosauria

Temnospondyla Edopoidea

Temnospondyla Mastodonsauroidea

Temnospondyla Stegoceophalia

Temnospondyla Stereospondylia

Synapsida

Therapsida

Therapsida

Therapsida

Therapsida
Basal Synapsida

Anomodontia

Cynodontia

Dicynodontia

Eutheriodontia

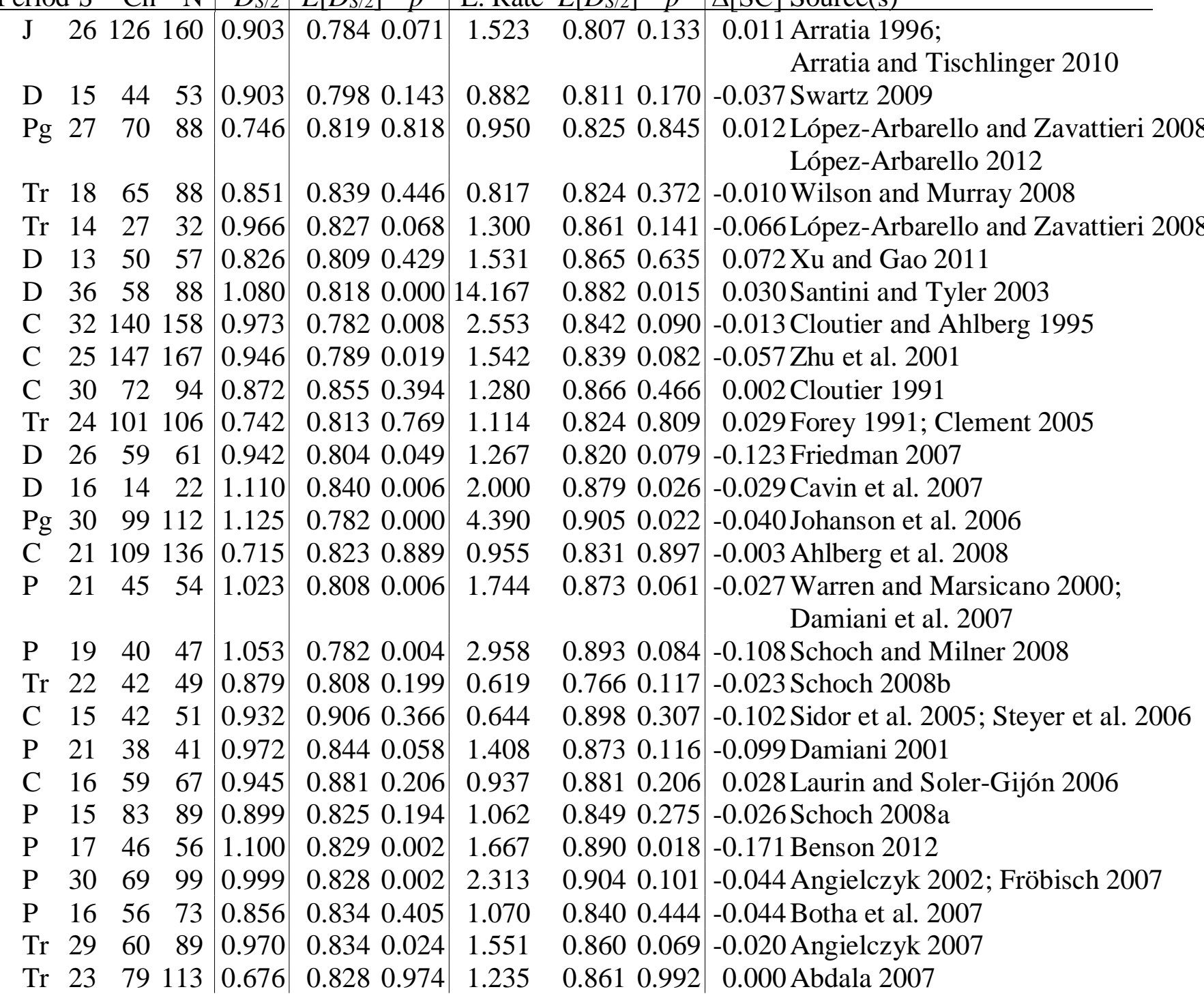

Arratia and Tischlinger 2010

\begin{tabular}{llll|l|l|lllll}
$\mathrm{D}$ & 15 & 44 & 53 & 0.903 & 0.798 & 0.143 & 0.882 & 0.811 & 0.170 & -0.037 Swartz 2009
\end{tabular}

López-Arbarello 2012

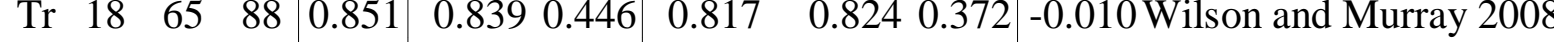

\begin{tabular}{llll|l|ll|lll|l}
$\operatorname{Tr}$ & 14 & 27 & 32 & 0.966 & 0.827 & 0.068 & 1.300 & 0.861 & 0.141 & -0.066López-Arbarello and Zavattieri 2008
\end{tabular}

\begin{tabular}{llll|l|l|l|l}
$\mathrm{D}$ & 13 & 50 & 57 & 0.826 & 0.809 & 0.429 & 1.531
\end{tabular}

$\begin{array}{lll}0.882 & 0.015 & 0.030 \text { Santini and Tyler } 2003\end{array}$

0.8420 .090 -0.013 Cloutier and Ahlberg 1995

$0.8390 .082-0.057$ Zhu et al. 2001

$0.8240 .809 \quad 0.029$ Forey 1991; Clement 2005

$\begin{array}{llll}0.820 & 0.079 & -0.123 \text { Friedman } 2007\end{array}$

$0.8790 .026-0.029$ Cavin et al. 2007

$0.9050 .022-0.040$ Johanson et al. 2006

$0.8310 .897-0.003$ Ahlberg et al. 2008

0.8730 .061 -0.027 Warren and Marsicano 2000;

$0.8930 .084-0.108$ Schoch and Milner 2008

$0.7660 .117-0.023$ Schoch $2008 b$

0.8730 .116 -0.099 Damiani 2001

0.8810 .206 0.028 Laurin and Soler-Gijón 2006

0.9040 .101 -0.044 Angielczyk 2002; Fröbisch 2007

$0.8600 .069-0.020$ Angielczyk 2007

\begin{tabular}{lll|l}
0.861 & 0.992 & 0.000 Abdala 2007
\end{tabular} 


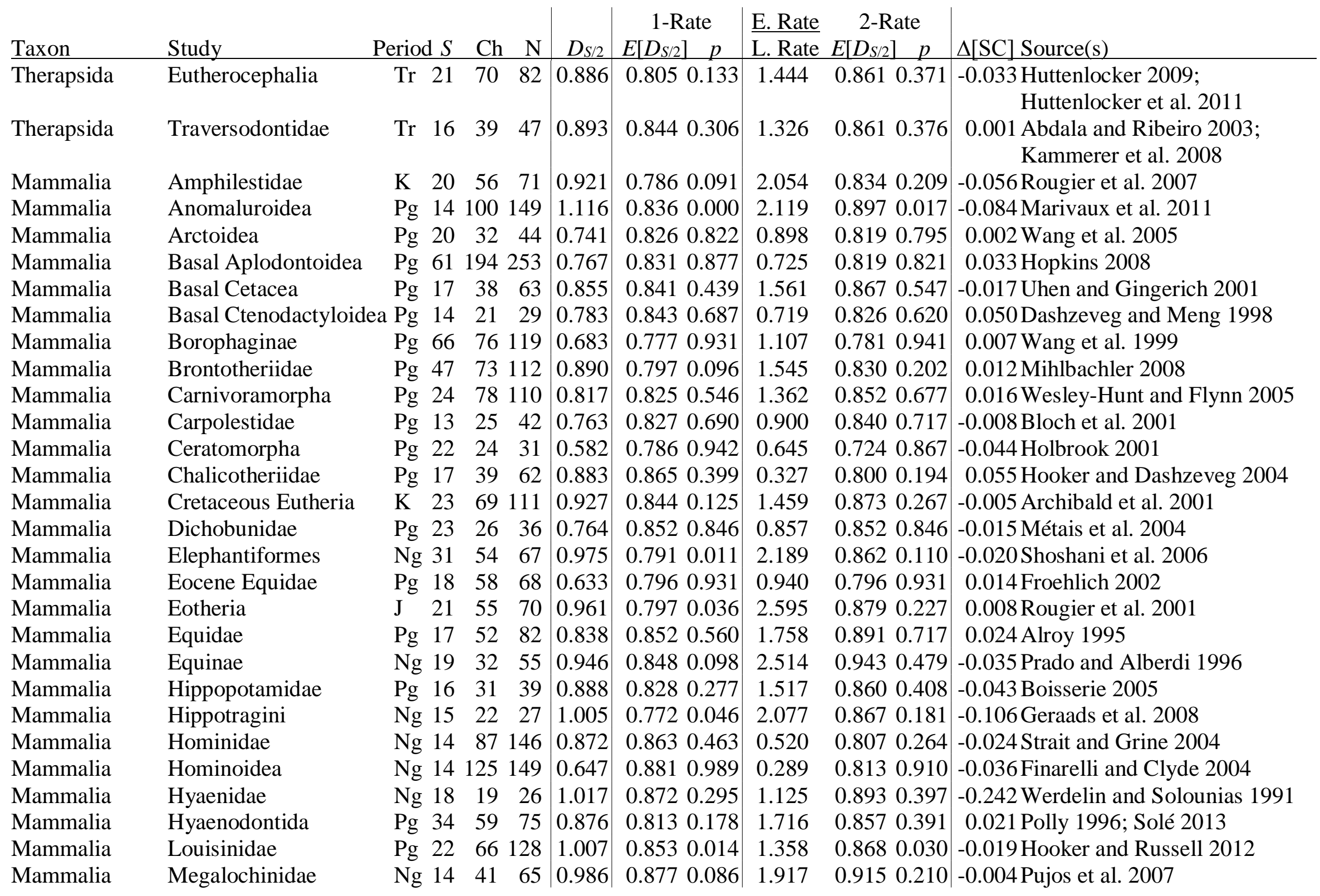




\begin{tabular}{|c|c|c|c|c|c|c|c|c|c|}
\hline Taxon & Study & Period $S$ & $\mathrm{Ch}$ & $\mathrm{N}$ & $D_{S / 2}$ & \begin{tabular}{c}
\multicolumn{2}{c}{ 1-Rate } \\
$E\left[D_{S / 2}\right] p$
\end{tabular} & $\begin{array}{l}\text { E. Rate } \\
\text { L. Rate }\end{array}$ & $\begin{array}{c}\text { 2-Rate } \\
E\left[D_{S / 2}\right] p\end{array}$ & $\Delta[\mathrm{SC}]$ Source $(\mathrm{s})$ \\
\hline Mammalia & Megalonychidae & $\mathrm{Ng} 14$ & 17 & 27 & 0.781 & 0.8640 .816 & 0.722 & 0.8390 .722 & -0.005 Carlini et al. 2009 \\
\hline Mammalia & Mioclaenidae & $\operatorname{Pg} 31$ & 50 & 73 & 0.873 & 0.8360 .297 & 0.881 & 0.8360 .297 & -0.034 Williamson and Carr 2007 \\
\hline Mammalia & Multituberculata & K 32 & 60 & 91 & 0.840 & 0.8450 .528 & 1.682 & 0.8690 .639 & 0.087 Kielan-Jaworowska and Hurum 2001 \\
\hline Mammalia & Mysticetiidae & $\mathrm{Ng} 32$ & 149 & 222 & 1.036 & 0.8120 .000 & 2.129 & 0.8520 .014 & -0.088 Bisconti 2007 \\
\hline Mammalia & Notohippidae & Pg 17 & 28 & 32 & 0.846 & 0.7630 .266 & 3.200 & 0.8390 .482 & 0.028 Shockey 1997 \\
\hline Mammalia & Odobenidae & $\mathrm{Ng} 14$ & 42 & 64 & 0.594 & 0.8110 .963 & 0.357 & 0.7200 .764 & 0.033 Kohno 2006 \\
\hline Mammalia & Omomyidae & Pg 29 & 279 & 391 & 0.851 & 0.8060 .227 & 1.874 & 0.8780 .643 & $0.022 \mathrm{Ni}$ et al. 2010 \\
\hline Mammalia & Paucituberculata & $\operatorname{Pg} 21$ & 42 & 62 & 0.775 & 0.8400 .807 & 0.905 & 0.8400 .807 & -0.017 Goin et al. 2009 \\
\hline Mammalia & Protoselendonta & $\operatorname{Pg} 23$ & 26 & 36 & 0.764 & 0.8450 .862 & 0.860 & 0.8450 .862 & -0.015 Grégoire et al. 2004 \\
\hline Mammalia & Selenodonta & $\operatorname{Pg} 22$ & 57 & 76 & 1.020 & 0.9060 .024 & 1.774 & 0.9340 .078 & 0.071 Métais 2006 \\
\hline Mammalia & Toxodontidae & $\mathrm{Ng} 20$ & 56 & 79 & 1.027 & 0.8670 .012 & 0.893 & 0.8640 .007 & 0.021 Nasif et al. 2000 \\
\hline Mammalia & Xenungulata & $\operatorname{Pg} 22$ & 20 & 49 & 0.976 & 0.8810 .067 & 2.029 & 0.9160 .190 & -0.037 Gelfo et al. 2008 \\
\hline Mammalia & Zapodidae & $\mathrm{Pg} 25$ & 28 & 36 & 0.867 & $\begin{array}{lll}0.833 & 0.322\end{array}$ & 1.022 & 0.8370 .343 & -0.018 López-Antoñanzas and Sen 2006 \\
\hline Anapsida & Ankyramorpha & P 19 & 86 & 100 & 1.063 & 0.8240 .001 & 2.083 & 0.8980 .029 & -0.035 Tsuji et al. 2010 \\
\hline Anapsida & Baenidae & K 14 & 51 & 57 & 0.971 & $\begin{array}{lll}0.832 & 0.099\end{array}$ & 0.932 & 0.8320 .099 & 0.031 Lyson and Joyce 2009 \\
\hline Anapsida & Basal Testudinata & J 33 & 90 & 102 & 0.993 & 0.7750 .012 & 1.661 & 0.8020 .043 & 0.017 Joyce 2007 \\
\hline Anapsida & Procolophonoidea & $\operatorname{Tr} 21$ & 37 & 52 & 0.731 & 0.8060 .798 & 1.227 & 0.8390 .876 & 0.022 Cisneros 2008 \\
\hline Ichthyosauria & Ichthyosauria & J 31 & 93 & 120 & 0.871 & 0.7980 .164 & 2.028 & 0.8780 .527 & -0.017 Motani 1999; Thorne et al. 2011 \\
\hline Sauropterygia & Mosasauridae & K 33 & 89 & 108 & 0.926 & 0.8270 .058 & 1.160 & 0.8440 .090 & -0.045 Bell 1997; \\
\hline
\end{tabular}

Christiansen and Bonde 2002;

Sauropterygia

Plesiosauroidea

Sphenodontia

\begin{tabular}{llll|l|l|l|l|l} 
J & 32 & 132 & 165 & 0.784 & 0.845 & 0.817 & 0.959
\end{tabular}

Dortangs et al. 2002

Sauropterygia

Archosauria

Archosauria

Archosauromorpha

\begin{tabular}{llll|l|l|l|l|l}
$\operatorname{Tr}$ & 22 & 47 & 63 & 1.011 & 0.880 & 0.020 & 1.577
\end{tabular}

\begin{tabular}{lllll|l|ll|l}
$\operatorname{Tr}$ & 20 & 130 & 153 & 0.887 & 0.837 & 0.255 & 1.471
\end{tabular}

\begin{tabular}{llll|l|l|l|l|l|l} 
Basal Crocodyliformes K 33 & 128 & 159 & 0.967 & 0.810 & 0.008 & 2.063
\end{tabular}

Basal Crurotarsia

\begin{tabular}{|l|l|l|l|l|l|l|l|}
$\mathrm{Tr}$ & 20 & 125 & 136 & 0.931 & 0.858 & 0.170 & 0.761 \\
\hline
\end{tabular}

\begin{tabular}{llll|l|l|l|l|}
$\mathrm{K}$ & 48 & 138 & 172 & 0.938 & 0.822 & 0.029 & 1.272
\end{tabular}

Archosauria

Crocodylia

Diplocynodontinae

Metriorhynchidae

Metriorhynchinae

\begin{tabular}{ll|l|l|l|l|l|l|}
$\mathrm{Pg}$ & 35 & 114 & 136 & 1.070 & 0.797 & 0.000 & 2.554 \\
\hline
\end{tabular}

\begin{tabular}{|llll|l|l|l|l|} 
J & 34 & 63 & 89 & 0.876 & 0.772 & 0.130 & 1.451
\end{tabular}

\begin{tabular}{llll|l|lll|l}
$\mathrm{J}$ & 18 & 42 & 67 & 0.612 & 0.797 & 0.958 & 0.610
\end{tabular}

Archosauria

Phytosauridae

\begin{tabular}{llll|l|l|l|l|l|}
$\operatorname{Tr}$ & 18 & 29 & 36 & 0.922 & 0.871 & 0.296 & 0.508
\end{tabular}

\begin{tabular}{ll|l}
0.845 & 0.817 & 0.003 O'Keefe 2001
\end{tabular}

$\begin{array}{llll}0.909 & 0.075 & -0.020 \text { Reynoso } 1996\end{array}$

\begin{tabular}{ll|l}
0.859 & 0.356 & 0.053 Dilkes 1998
\end{tabular}

$\begin{array}{lll}0.869 & 0.117 & -0.066 \text { Salisbury et al. } 2006\end{array}$

$0.8420 .110-0.032$ Brusatte et al. 2010a

0.8320 .049 -0.033 Brochu 1997; Zaher et al. 2006

\begin{tabular}{ll|l}
0.890 & 0.023 & -0.061 Piras and Buscalioni 2006
\end{tabular}

$0.8040 .221 \quad 0.016$ Young and De Andrade 2009

0.7770 .9130 .062 Wilkinson et al. 2008

\begin{tabular}{ll|l}
0.844 & 0.235 & -0.089
\end{tabular} Stocker 2010; Stocker 2012 


\begin{tabular}{|c|c|c|c|c|c|c|c|c|c|c|}
\hline Taxon & Study & Perio & & $\mathrm{Ch}$ & $\mathrm{N}$ & $D_{S / 2}$ & $\begin{array}{c}\text { 1-Rate } \\
E\left[D_{S / 2}\right] p\end{array}$ & $\frac{\text { E. Rate }}{\text { L. Rate }}$ & $\begin{array}{c}\text { 2-Rate } \\
E\left\lceil D_{S / 2}\right] \quad p\end{array}$ & $\Delta[\mathrm{SC}]$ Source $(\mathrm{s})$ \\
\hline Archosauria & Protosuchidae & $\mathrm{J}$ & 14 & 134 & 147 & 0.876 & 0.8230 .287 & 0.993 & $0.823 \quad 0.287$ & 0.008 Gasparini et al. 2006 \\
\hline Archosauria & Sebecosuchia & $\mathrm{Pg}$ & 16 & 29 & 36 & 1.045 & 0.7860 .042 & 1.136 & 0.8020 .050 & -0.054 Pol et al. 2012; Kellner et al. 20 \\
\hline Archosauria & Basal Pterosauria & $\mathrm{J}$ & 18 & 71 & 82 & 0.916 & 0.7970 .111 & 2.585 & 0.8770 .376 & 0.013 Andres et al. 2010 \\
\hline Archosauria & Pterosauria & $\mathrm{J}$ & 56 & 117 & 160 & 0.877 & 0.8020 .114 & 1.789 & 0.8350 .255 & -0.030 Lü et al. 2010 \\
\hline Archosauria & Ankylosauria & $\mathrm{K}$ & 45 & 140 & 149 & 0.869 & 0.8860 .629 & 1.485 & $\begin{array}{lll}0.901 & 0.727\end{array}$ & 0.010 Thompson et al. 2012 \\
\hline Archosauria & Ankylosauroidea & $\mathrm{K}$ & 16 & 54 & 65 & 0.933 & 0.9180 .422 & 1.009 & 0.9260 .461 & 0.051 Ösi 2005 \\
\hline Archosauria & Basal Iguanodontia & $\mathrm{J}$ & 21 & 31 & 38 & 0.856 & 0.8480 .470 & 1.515 & 0.9000 .668 & 0.045 McDonald 2012 \\
\hline Archosauria & Ceratopsidae & $\mathrm{K}$ & 13 & 17 & 22 & 0.816 & 0.7670 .352 & 2.750 & 0.9110 .666 & $-0.014 \mathrm{Wu}$ et al. 2007 \\
\hline Archosauria & Ceratosauria & $\mathrm{K}$ & 18 & 27 & 28 & 0.928 & 0.8030 .215 & 4.875 & 0.9570 .567 & 0.001 Carrano and Sampson \\
\hline Archosauria & Chasmosaurinae & K & 18 & 61 & 75 & 0.844 & 0.8440 .501 & 1.123 & $\begin{array}{lll}0.851 & 0.534\end{array}$ & 0.020 Sampson et al. 2010 \\
\hline Archosauria & Deinonychosauria & $\mathrm{K}$ & 17 & 75 & 83 & 1.038 & 0.8120 .010 & 1.926 & 0.8560 .049 & $\begin{array}{l}\text { 0.053 Makovicky and Sues 1998; } \\
\text { Xu et al. 2002a; Hwang et al. } 200\end{array}$ \\
\hline Arch & 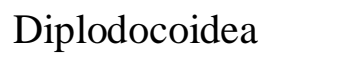 & $\mathrm{J}$ & 20 & 106 & 107 & 0.723 & 0.7980 .759 & 1.133 & 0.8100 .796 & 0.035 Whitlock 2011 \\
\hline Archosauria & Dromaeosauridae & K & 17 & 108 & 115 & 1.167 & 0.8320 .003 & 3.476 & 0.8990 .022 & -0.055 Zheng et al. 2010 \\
\hline Archosauria & Hadrosauroidea & $\mathrm{K}$ & 29 & 126 & 143 & 0.929 & 0.7740 .011 & 2.145 & 0.8560 .195 & -0.063 Sues and Averianov 2009 \\
\hline Archosauria & Megalosauroidea & $\mathrm{J}$ & 15 & 34 & 37 & 0.545 & 0.7620 .953 & 0.629 & 0.7290 .921 & -0.021 Benson et al. 2010 \\
\hline Archosauria & Neoceratopsia & $\mathrm{K}$ & 18 & 110 & 131 & 0.806 & 0.8150 .537 & 0.795 & 0.7990 .476 & $\begin{array}{l}\text {-0.008 Makovicky and Norell 2006; } \\
\text { Zhao et al. } 2006\end{array}$ \\
\hline Archo: & Orni & $\mathrm{K}$ & 14 & 72 & 75 & 0.874 & 0.8450 .375 & 1.169 & 0.8600 .437 & -0.140 Weishampel et al. 2003 \\
\hline Archosauria & Oviraptosauria & K & 13 & 39 & 42 & 1.236 & 0.8250 .003 & 10.800 & 0.9310 .047 & $-0.114 \mathrm{Xu}$ et al. $2002 \mathrm{~b} ; \mathrm{Xu}$ et al. $2002 \mathrm{a}$ \\
\hline Archosauria & Prosauropoda & $\operatorname{Tr}$ & 15 & 110 & 110 & 1.018 & 0.8450 .035 & 1.211 & 0.8700 .061 & 0.039 Yates 2003 \\
\hline Archosauria & Saurolophidae & $\mathrm{K}$ & 28 & 210 & 295 & 0.969 & 0.8130 .011 & 1.361 & 0.8490 .029 & -0.046 Prieto-Márquez 2010 \\
\hline Archosauria & Sauropoda & $\mathrm{J}$ & 28 & 270 & 340 & 0.847 & 0.8580 .595 & 1.142 & 0.8750 .683 & 0.033 Harris 2006 \\
\hline Archosauria & Titanosauriformes & $\mathrm{K}$ & 21 & 64 & 67 & 0.786 & 0.7790 .478 & 1.333 & 0.8180 .602 & -0.041 D'Emic 2012 \\
\hline Archosauria & Tyranosauroidea & $\mathrm{K}$ & 19 & 284 & 324 & $\mid 0.658$ & 0.7590 .879 & 1.631 & 0.8170 .953 & 0.014 Brusatte et al. $2010 \mathrm{~b}$ \\
\hline
\end{tabular}

"Period" gives the geochronological period from which most taxa in an analysis are known: $\mathrm{Cm}=\mathrm{Cambrian}$; O=Ordovician; $\mathrm{S}=$ Silurian; $\mathrm{D}=$ Devonian; $\mathrm{C}=$ Carboniferous; $\mathrm{P}=$ Permian; $\mathrm{Tr}=$ Triassic; $\mathrm{J}=\mathrm{J}$ urassic; $\mathrm{K}=$ Cretaceous; $\mathrm{Pg}=\mathrm{Paleogene}$; $\mathrm{Ng}=\mathrm{Neogene}$. "S" = Number of taxa. "Ch"= Number of characters. "N" = Number of novel states (= Number of characters if all characters are binary). $D_{S / 2}=$ Disparity as average pairwise dissimilarity between taxa among the first half of all $S$ taxa. This is a proportion of 
the disparity among all $S$ taxa; note that disparity can decrease (yielding $D_{S / 2}>1$ ) when the latter half of diversification largely fills in existing morphospace. $E\left[D_{S / 2}\right]$ gives the expected disparity among the first $\mathrm{S} / 2$ taxa given either a uniform rate (1-rate) of independent change or a separate early and late rate (2-Rate) of change given 1000 Monte Carlo simulations, where the rates maximize the probability of the observed compatibility among either all $S$ taxa (1-Rate) or the earliest $S / 2$ taxa (2-rate). $P\left[D_{S / 2}\right]$ gives the proportion of Monte Carlo runs generating $D_{S / 2}$ equaling or surpassing the observed. $\frac{\text { Early Rate }}{\text { Late Rate }}$ gives the proportional difference between the early and late rates. $\Delta[\mathrm{SC}]$ gives the difference between observed and expected stratigraphic compatibility based on the same Monte Carlo analyses assuming the 2-rate model of independent change. 